\title{
Mechanisms of lower extremity vein dysfunction in chronic venous disease and implications in management of varicose veins
}

\author{
Joseph D. Raffetto, Raouf A. Khalil \\ Vascular Surgery Research Laboratories, Division of Vascular and Endovascular Surgery, Brigham and Women's Hospital, and \\ Harvard Medical School, Boston, MA 02115, USA. \\ Correspondence to: Dr. Raouf A. Khalil, Vascular Surgery Research Laboratories, Division of Vascular and Endovascular Surgery, \\ Brigham and Women's Hospital, and Harvard Medical School, 75 Francis Street, Boston, MA 02115, USA. \\ E-mail: raouf_khalil@hms.harvard.edu
}

How to cite this article: Raffetto JD, Khalil RA. Mechanisms of lower extremity vein dysfunction in chronic venous disease and implications in management of varicose veins. Vessel Plus 2021;5:36. https://dx.doi.org/10.20517/2574-1209.2021.16

Received: 8 Feb 2021 Accepted: 10 May 2021 First online: 29 May 2021

Academic Editors: Rene Gordon Holzheimer, Markus Stücker Copy Editor: Xi-Jun Chen Production Editor: Xi-Jun Chen

\begin{abstract}
Chronic venous disease (CVD) is a common venous disorder of the lower extremities. CVD can be manifested as varicose veins (VVs), with dilated and tortuous veins, dysfunctional valves and venous reflux. If not adequately treated, VVs could progress to chronic venous insufficiency (CVI) and lead to venous leg ulcer (VLU). Predisposing familial and genetic factors have been implicated in CVD. Additional environmental, behavioral and dietary factors including sedentary lifestyle and obesity may also contribute to CVD. Alterations in the mRNA expression, protein levels and proteolytic activity of matrix metalloproteinases (MMPs) have been detected in VVs and VLU. MMP expression/activity can be modulated by venous hydrostatic pressure, hypoxia, tissue metabolites, and inflammation. MMPs in turn increase proteolysis of different protein substrates in the extracellular matrix particularly collagen and elastin, leading to weakening of the vein wall. MMPs could also promote venous dilation by increasing the release of endothelium-derived vasodilators and activating potassium channels, leading to smooth muscle hyperpolarization and relaxation. Depending on VVs severity, management usually includes compression stockings, sclerotherapy and surgical removal. Venotonics have also been promoted to decrease the progression of VVs. Sulodexide has also shown benefits in VLU and CVI, and recent data suggest that it could improve venous smooth muscle contraction. Other lines of treatment including induction of endogenous tissue inhibitors of metalloproteinases and administration of exogenous synthetic inhibitors of MMPs are being explored, and could provide alternative strategies in the treatment of CVD.
\end{abstract}


Keywords: Extracellular matrix, matrix metalloproteinases, remodeling, varicose veins, vascular smooth muscle

\section{INTRODUCTION}

Chronic venous disease (CVD) is a common venous disorder characterized by dilation of the veins of the lower extremities and often varicose veins (VVs). If not treated in a timely fashion, VVs could progress to chronic venous insufficiency (CVI) and lead to skin changes and venous leg ulcer (VLU). VVs could also be associated with other venous conditions such as thrombophlebitis and deep venous thrombosis (DVT). Investigating the risk factors and mechanisms underlying CVD should help to develop effective treatment strategies.

Family history and several genetic factors have been implicated in VVs. Environmental factors including sedentary lifestyle and obesity may also contribute to the development of CVD. Changes in the levels/activity of matrix metalloproteinases (MMPs) have also been detected in $\mathrm{VVs}^{[1,2]}$. MMPs are $\mathrm{Zn}^{2+}-$ dependent endopeptidases that cause degradation of different protein substrates in the extracellular matrix (ECM). MMP mRNA expression, protein levels and proteolytic activity can be modulated by numerous factors including venous hydrostatic pressure, hypoxia, tissue metabolites and the inflammatory response. MMPs could promote remodeling of venous tissue through proteolytic degradation of different components of ECM. MMPs could also affect vascular smooth muscle (VSM) cell proliferation, migration, differentiation and/or apoptosis. MMPs have also been shown to affect endothelial function and VSM contraction mechanisms ${ }^{[3,4]}$. MMPs are negatively controlled by endogenous tissue inhibitors of metalloproteinases (TIMPs), and an imbalance between MMPs and TIMPs could contribute to venous dysfunction and $\mathrm{CVD}^{[1,5]}$.

Management of CVD includes elastic compression stocking, inelastic garments, multilayerd bandaging, sclerotherapy, endvenous therapies, and surgical removal, but with variable results and high recurrence rates, making it important to find new approaches. Venotonics are being promoted to limit the progression of VVs. Sulodexide (SDX) has shown benefits in VLU, and may have venotonic properties by inhibiting MMPs and improving venous VSM contraction ${ }^{[6,7]}$. Understanding the role of MMPs, their differential levels and distribution in VVs, and their endogenous and synthetic inhibitors could also provide new approaches in the treatment of CVD.

This review will highlight reports published in PubMed and Web of Science together with data from our research laboratory to provide insights on the mechanisms and potential therapies for CVD. We will discuss the different abnormalities in the lower extremity vein structure and function observed in CVD and VVs. We will describe how genetic background and environmental factors could predispose to and increase the risk for CVD. We will then describe the alterations in MMP levels in VVs, and the different factors modulating MMP expression and activity including changes in the lower extremity venous hydrostatic pressure, hypoxia, tissue metabolites and the inflammatory response. We will also discuss how MMPs not only increase ECM turnover, but also cause endothelial cell dysfunction and reduce VSM contraction mechanisms, leading to progression of venous dilation and VVs. Lastly, we will summarize some of the medical and surgical strategies used for management of VVs, and discuss some of the reported benefits of venotonics, sulodexide and MMP endogenous and exogenous inhibitors and their potential use in the treatment of VVs and in retarding the progression of CVD. 


\section{CHRONIC VENOUS DISEASE}

CVD is a common venous disorder of the lower limb veins with several socio-economic consequences. Based on the clinical-etiology-anatomy-pathophysiology (CEAP) categorization, CVD is classified into clinical stages Co-C6. The Co stage indicates no visible signs of CVD. The C1 stage shows telangiectasises or spider veins. C2 is manifested as VVs. C3 involves tissue edema. C4a is presented as eczema or skin pigmentation and $\mathrm{C} 4 \mathrm{~b}$ is associated with atrophie blanche or lipodermatosclerosis. $\mathrm{C} 5$ indicates healed VLU, and C6 presents as active VLU. The advanced CVD stages $\mathrm{C} 4-\mathrm{C} 6$ are often designated as $\mathrm{CVI}^{[8]}$. A recently published revision of the classification for CEAP has also included C2r for recurrent VVs, C4c for corona phlebectatica (a risk factor for VLU), and Cor for recurrent active VLU ${ }^{[0]}$.

VVs of the lower extremities affect approximately 25 million of the adult population in the United States ${ }^{[10]}$. VVs are commonly manifested as large, distended, engorged and tortuous lower limb superficial veins. VVs are also associated with incompetent and dysfunctional venous valves and significant venous reflux. The superficial VVs typically show a venous reflux and backflow of blood that is maintained for a time period greater than half a second ${ }^{[11]}$. Although VVs are often thought of as a localized dysfunction in the lower limb veins, pathological changes may be present in other distant veins beyond those in the lower limb. In effect, VVs may be one component of a more generalized pathology of the venous system, and it manifests in the lower extremity veins due to the high venous hydrostatic pressure. This is supported by the observation that the arm veins of VVs patients also show increased distensibility ${ }^{[12]}$. VVs could have major socioeconomic impact and their unsightly appearance could cause significant psychological distress. If untreated, VVs can progress to CVI with VLU, and may be associated with other venous conditions such as thrombophlebitis and $\mathrm{DVT}^{[8]}$.

\section{Abnormal vein structure and function in VVs}

VVs usually manifest as engorged and dilated veins, which could be interpreted as mainly hypertrophic tissue remodeling in the lower extremity veins. However, careful examination of the vein structure and histology has shown that VVs could have both hypertrophic and atrophic regions [Figure 1] ${ }^{[13]}$. The VVs hypertrophic regions usually demonstrate abnormal shape and orientation of VSM cells (VSMCs) and extensive deposition of ECM. On the other hand, the VVs atrophic regions usually demonstrate extensive degradation of ECM and tissue infiltration of inflammatory cells ${ }^{[14]}$. VVs tissue histology shows no clear vascular layers, and lack of distinct boundaries between the tunica intima, tunica media, and the adventitia. VVs tissue sections may also show focal thickening of the intima, and increased tunica media thickening with fragmentated elastin fibers ${ }^{[15]}$. In VVs tissue sections, VSMCs are disorganized in the tunica media and in the vicinity of the intima, with poorly-defined nonstructured materials. The collagen fibers in VVs sections are also disorganized and make it difficult to demarcate between the tunica media and the adventitia, whereas the elastic fibers are thick and fragmented in both the tunica intima and the adventitia ${ }^{[2]}$.

VVs also demonstrate an imbalance between the main components of ECM proteins with marked changes in tissue content of collagen and elastin. Measurements of tissue collagen varied between an increase ${ }^{[16]}$, a decrease $^{[17]}$, or no difference in VVs compared with control veins ${ }^{[18]}$. Cultured VSMCs and dermal fibroblasts from patients with CVD and VVs have demonstrated elevated protein levels of collagen type-I and reduced collagen type-III, with no detectable alteration in gene transcription, suggesting posttranslational modification of collagen type-III. It has also been shown that the transcription of collagen type-III is normal in VSMCs from VVs, while MMP-3 activity is increased leading to post-translational proteolysis of collagen type-III. In support, collagen type-III production was partially restored in VSMCs from VVs in the presence of the MMP inhibitor marimastat ${ }^{[19]}$. Collagen type-III is very important as it determines the blood vessel distensibility and elasticity, and alterations in collagen synthesis and/or 
A Normal Vein

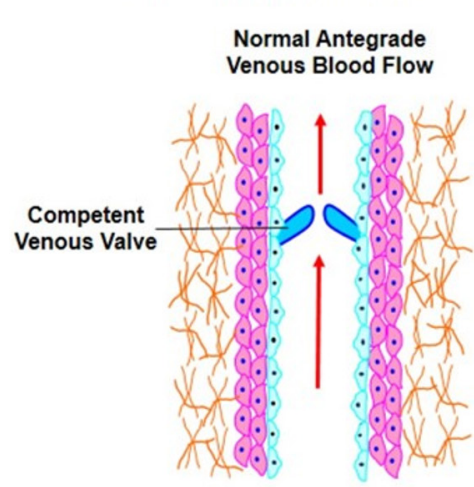

B Varicose Vein

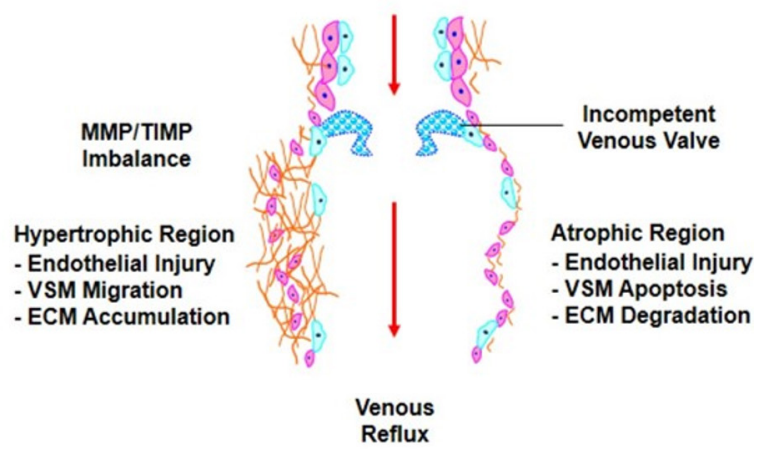

Figure 1. Vein wall, venous valves and blood flow in normal veins and $V V s$. In normal veins, competent venous valves allow blood flow in an antegrade direction towards the heart (A). In CVD, vein dysfunction could progress to large dilated VVs with incompetent valves. VVs show atrophic regions where increases in MMP levels promote ECM degradation, as well as hypertrophic regions in which MMP/TIMP imbalance would allow ECM accumulation, leading to dilated and tortuous vein wall, defective valves, and venous reflux (B). VVs: Varicose veins; CVD: chronic venous disease; MMP: matrix metalloproteinases; ECM: extracellular matrix; TIMP: tissue inhibitors of metalloproteinase.

proteolysis and in turn the ratio between collagen type-I and type-III could negatively affect the vein wall integrity, and lead to weakening of the vein wall, venous dilation, and VVs formation ${ }^{[2]}$. Some studies suggest that a decrease in elastin could reduce the elasticicity of the vein wall and lead to venous dilation and $\mathrm{VVs}^{[20]}$, but other reports suggest an increase in the elastin network in $\mathrm{VVs}^{[2]}$.

Besides the pathological alterations in the vein wall, VVs also show incompetent and dysfunctional venous valves. However, whether venous valve incompetence occurs first and leads to dilation of the vein wall or vice versa is unclear. One hypothesis is that a primary valve incompetence could cause venous reflux and elevate the lower limb venous hydrostatic pressure leading to initial dilation of the vein wall. The dilated segments of the vein wall near the vein valves would then cause more distortion in the valves, leading to progressive increases in venous reflux, venous hydrostatic pressure and vein wall dilation. This hypothesis is supported by the findings that VVs show hypertrophic venous valves, augmented valvular annulus width ${ }^{[21]}$, reduced viscoelasticity and collagen content ${ }^{[22]}$, and increased inflammatory cells and monocyte and macrophage infiltration of the valvular sinuses as compared to distal VVs walls ${ }^{[23]}$. However, this hypothesis has been contested by the finding that VVs are sometimes detected below competent and functional venous valves $^{[13]}$. Also, changes in collagen and elastin are detected in both the varices segments of VVs and the apparently normal vein segments near the varices, which suggests that changes in ECM proteins occur in the vein wall before valve dysfunction ${ }^{[16]}$. Notably, VVs develop not only in a retrograde manner from the thigh to the calf and the ankle, but also in an antegrade fashion in the normal direction of venous flow from the ankle to the calf and the thigh, likely due to primary dilation in the vein wall that could then lead to valve insufficiency ${ }^{[1,13]}$. Regardless of what happens first, both vein wall dilation and venous valve incompetence are involved in the pathogenesis of VVs.

\section{Predisposing demographic and environmental factors in CVD}

Several demographic and predisposing factors could increase the risk for VVs including old age, female sex, use of contraceptive pills and estrogen therapy, pregnancy, overweight and obesity, history of leg injury, and venous inflammation and phlebitis. Estrogen activates estrogen receptors in the vein wall and in turn increases venous dilation. Some studies suggest that CVD is more prevalent in females than males ${ }^{[12]}$. For 
instance, the Framingham Study showed a greater annual incidence of VVs in women (2.6\%) than in men $(1.9 \%)^{[13]}$. Also, the Edinburgh Vein Study screened for CVD in 1566 subjects 18-64 years old at 12 general practices and showed that females reported more leg symptoms ${ }^{[14]}$. However, a follow-up study found that the age-adjusted prevalence of truncal VVs was $\sim 40 \%$ in males and $\sim 32 \%$ in females, and VVs and CVD prevalence increased with age in both $\operatorname{sexes}^{[15]}$. Also, studies using Duplex ultrasound to evaluate venous reflux reported CVD in $\sim 9.4 \%$ of males and $\sim 6.6 \%$ of females, and an increase in the incidence with age to $\sim 21.2 \%$ in males older than 50 , and to $\sim 12.0 \%$ in females older than $50^{[16]}$. Interestingly, we have shown that $\alpha$-adrenergic-, angiotensin II (AngII)-, depolarization-induced, and $\left[\mathrm{Ca}^{2+}\right]$-dependent venous tissue contraction are less in female than in male rat inferior vena cava (IVC), likely because of increased expression and activity of estrogen receptors and increased endothelium-dependent venous relaxation pathways in female compared with male rats. These observations suggested gender differences in venous function, enhanced estrogen-induced venous relaxation pathways and decreased mechanisms of VSM contraction, leading to more distention of the venous wall in females ${ }^{[24]}$.

Overweight and obesity in women increase the risk of developing $\mathrm{VVs}^{[25]}$. Compared with lean women, women with moderate overweight $\left(\mathrm{BMI}=25.0-29.9 \mathrm{~kg} / \mathrm{m}^{2}\right)$ were more likely to present with VVs, and obese women $\left(\mathrm{BMI} \geq 30 \mathrm{~kg} / \mathrm{m}^{2}\right)$ were 3 times more likely to present with VVs. On the other hand, a positive relation between BMI and CVD was not observed among men $^{[26]}$. Of note, the plasma levels of total and bioavailable estrogens are greater in overweight and obese women compared with lean women particularly in the postmenopausal period ${ }^{[27]}$, further highlighting the positive association between plasma estrogen levels and the incidence of VVs.

Pregnancy involves important physiological changes that could promote venous dilation and VVs formation. Plasma levels of estrogen and progesterone are elevated during pregnancy ${ }^{[28]}$. Also, increased blood volume and plasma volume expansion occur during early pregnancy ${ }^{[29]}$. The progressive fetal growth and weight gain during pregnancy also cause increases in intra-abdominal pressure and central venous return $^{[30,31]}$, which could cause venous valve incompetence and further progression of VVs.

Behavioral factors including prolonged sitting or standing and sedentary lifestyle could represent a risk for $\mathrm{CVD}^{[2,32,33]}$. Also, the physical activity and ergonomics of an occupation and a work place may influence VVs epidemiology. In a community-based study on males and females of 20 to 64 years old in Jerusalem, the VVs prevalence was higher in individuals spending most of their workday in a standing position. Also, reporting of occupations requiring prolonged standing was higher in females (31.4\%) compared with males $(13.6 \%)$, although the ratio of standing $v s$. sitting workplace posture was higher in men (1.88) than in women $(1.53)^{[34]}$.

\section{Predisposing hereditary and genetic factors in CVD}

Family history, hereditary and genetic factors could increase the risk for VVs [Table 1] ${ }^{[35,36]}$. The lower extremity venous hemodynamics and elasticity of the vein wall are decreased in the children of patients with $\mathrm{VVs}^{[37]}$. Of note, the VVs pathology may not be restricted to the lower limb veins, and patients with VVs may show abnormal increase in distensibility of the arm veins, which suggests a more generalized and systemic disorder of the vein wall ${ }^{[12]}$. There is also an increasing evidence of a genetic component in VVs. Microarray analysis of 3063 cDNAs from patients with VVs demonstrated an upregulation of 82 genes, especially those involved in the regulation of myofibroblasts, cytoskeletal proteins and $\mathrm{ECM}^{[35]}$. An elegant study of nearly half a million subjects (control and cases), utilizing machine learning for risk factors as well as genome-wide association study (GWAS), implicated advanced age, female sex, obesity, pregnancy, DVT, increased height, and leg bioimpedance as risk factors for VVs. The GWAS found 30 novel genome loci that 
Table 1. Representative genetic factors in VVs and venous leg ulcer

\begin{tabular}{|c|c|c|c|}
\hline $\begin{array}{l}\text { Gene chromosome } \\
\text { locus, variants }\end{array}$ & Disease & Manifestations & Ref. \\
\hline $\begin{array}{l}\text { COL3A1, COL5A1, } \\
\text { ADAMTS2 }\end{array}$ & Ehlers-Danlos syndrome & $\begin{array}{l}\text { Connective tissue disorders, abnormal collagen synthesis, joint } \\
\text { hypermobility, distensible skin, ocular disease, bone } \\
\text { deformities and fragility, vascular and visceral tissue wall } \\
\text { fragility and susceptibility to rupture, VVs }\end{array}$ & {$[39,224]$} \\
\hline $\begin{array}{l}\text { von-Hippel Lindau } \\
\text { gene mutation } \\
3 \mathrm{p} 25 \\
598>T\end{array}$ & Chuvash polycythemia & $\begin{array}{l}\text { Defective oxygen sensing, increased HIF- } 1 \alpha \text {, increased serum } \\
\text { erythropoietin and hemoglobin, } \mathrm{VV} \text { s, tendency for vertebral } \\
\text { hemangiomas, thrombosis, bleeding, and stroke }\end{array}$ & {$[225-227]$} \\
\hline G6PC3 gene mutation & $\begin{array}{l}\text { Severe congenital neutropenia } \\
\text { type } 4\end{array}$ & VVs, venous leg ulcer & {$[228]$} \\
\hline $\begin{array}{l}\text { Desmuslin gene } \\
\text { deficiency } \\
15 \mathrm{q} 26.3\end{array}$ & VVs & $\begin{array}{l}\text { Decreased intermediate filament protein desmuslin in VSM, } \\
\text { smooth muscle switch from contractile to synthetic phenotype, } \\
\text { weakening of vein wall, venous dilation. Increased MMP- } 2 \text { and } \\
\text { collagen }\end{array}$ & {$[48,117,120,229,230]$} \\
\hline $\begin{array}{l}\text { Thrombomodulin (- } \\
\text { 1208/-1209 TT } \\
\text { deletion) }\end{array}$ & Deep venous thrombosis, VVs & Dysregulation of thrombin, thrombus formation & [231] \\
\hline $\begin{array}{l}\text { Translocation of } \\
\text { chromosome } 8 \mathrm{q} 22.3 \\
\& 14 q 13 \\
\text { Ell3K or VG5Q gene } \\
\text { mutation on } \\
\text { chromosome } 5\end{array}$ & Klippel-Trenaunay syndrome & $\begin{array}{l}\text { Cutaneous capillary } \\
\text { malformations (port wine stain), VVs, bone and soft tissues } \\
\text { hypertrophy }\end{array}$ & {$[232,233]$} \\
\hline $\begin{array}{l}\text { FOXC2 gene mutation } \\
16 \mathrm{q} 24.3\end{array}$ & Lymphoedema distichiasis & $\begin{array}{l}\text { Lymphedema, distichiasis (extra eyelashes from meibomian } \\
\text { glands), VVs, congenital heart defects, vertebral anomalies, } \\
\text { extradural cysts, ptosis, cleft palate }\end{array}$ & {$[234-236]$} \\
\hline $\begin{array}{l}\text { Notch3 gene mutation } \\
1279 \mathrm{G}>\mathrm{T}\end{array}$ & CADASIL & $\begin{array}{l}\text { Cerebral autosomal-dominant arteriopathy with subcortical } \\
\text { infarcts and leukoencephalopathy, VVs }\end{array}$ & [46] \\
\hline $\begin{array}{l}\text { Trisomies } \\
\text { chromosomes 7, 12, } 18 \\
\text { Monosomy } \\
\text { chromosome } 14\end{array}$ & VVs & Abnormalities in cell lines from patients with $\mathrm{VVs}$ & {$[237]$} \\
\hline F13A1 gene & Factor XIII deficiency & Delayed venous ulcer healing & [54] \\
\hline $\begin{array}{l}\text { HFE gene mutation } \\
\text { C282Y and } \mathrm{H} 63 \mathrm{D}\end{array}$ & Increased iron deposition & Venous ulcer exacerbation & [51] \\
\hline $\begin{array}{l}\text { MTFR gene } \\
\text { SNP C 677T }\end{array}$ & $\begin{array}{l}\text { Decreased } \\
\text { methylenetetrahydrofolate } \\
\text { reductase activity }\end{array}$ & Hyperhomocystinemia, VVs, CVI & {$[238,239]$} \\
\hline $\begin{array}{l}\text { SLC4OA1 } \\
\text { SNP 8CG }\end{array}$ & $\begin{array}{l}\text { Impaired iron metabolism, } \\
\text { increased iron deposition }\end{array}$ & $C V D$, venous ulcer & {$[240]$} \\
\hline $\begin{array}{l}\text { MMP-12 } \\
\text { SNP 82AA }\end{array}$ & Altered MMP activity & Venous ulcer & {$[240]$} \\
\hline $\begin{array}{l}\text { FGFR-2 } \\
\text { SNP 2451AG }\end{array}$ & $\begin{array}{l}\text { mRNA instability, reduced } \\
\text { wound healing }\end{array}$ & CVI, non-healing venous ulcer & {$[241]$} \\
\hline
\end{tabular}

VVs: Varicose veins; VSM: vascular smooth muscle; MMP: matrix metalloproteinases; CADASIL: cerebral autosomal dominant arteriopathy with subcortical infarcts and leukoencephalopathy; CVI: chronic venous insufficiency; CVD: chronic venous disease.

were robustly associated with VVs, including genes encoding for blood pressure, vascular mechanosensing channels, vascular maturation, development and integrity, and genes near the hemochromatosis gene that is strongly associated with VLU and DVT ${ }^{[38]}$. Patients with Ehlers-Danlos syndrome show increased propensity to developing vascular pathologies and VVs ${ }^{[39]}$. Ehlers-Danlos syndrome includes several connective tissue disorders that involve abnormal collagen synthesis and could be manifested in the form of distensible skin, joint hypermobility, bone fragility and deformity, ocular disease, and cardiovascular and visceral disorders in which the blood vessels and visceral tissue walls become more fragile and prone to rupture. Patients with vascular Ehlers-Danlos syndrome have defective COL3A1 gene and are more susceptible to vascular disease and $\mathrm{VVs}^{[3,40]}$. Of note, patients with hereditary connective tissue syndromes 
do not always report VVs. For example, Marfan syndrome, an autosomal dominant connective tissue disorder with a mutation in the FBN1 gene that codes for fibrillin-1 and promotes elastic fiber synthesis ${ }^{[41]}$, mainly affects the aorta and heart valves, but unlike Ehlers-Danlos syndrome, it does not present with VVs.

Primary lymphedema-distichiasis is a rare syndrome that involves a mutation in the FOXC2 gene on chromosome $16 \mathrm{q} 24$ and is associated with VVs in early age ${ }^{[22,43]}$. A genealogical tree study in 9 families has shown a link between VVs and the candidate marker D16S520 on chromosome 16q24, which may explain the linkage to FOXC2 gene. Saphenofemoral junction reflux was also found in families of affected patients with the D16S520 marker. The linkage to a candidate marker for the FOXC2 gene suggests a functional gene variant that predisposes to VVs, and a heritable autosomal dominant CVI with incomplete penetrance ${ }^{[43]}$. Patients with Klippel-Trenaunay Syndrome present with congenital venous anomalies including atresia, agenesis of the deep veins, valve incompetence, venous aneurysms, and embryonic veins ${ }^{[44]}$. Patients could also present with impaired venous muscle pump function, VVs, limb hypertrophy, and dermal capillary hemangiomas or port wine stain ${ }^{[45]}$. The lymphatic system can also be involved and show pathological changes in this syndrome. A heterozygous Notch 3 gene mutation has been detected in the CADASIL (cerebral autosomal dominant arteriopathy with subcortical infarcts and leukoencephalopathy) pedigree with $\mathrm{VVs}^{[46]}$.

A single nucleotide polymorphism (SNP) - 1562C/T in the promoter region of MMP-9 gene has been linked to increased promoter activity and plasma levels of MMP-9 and VVs in the Chinese population ${ }^{[47]}$. Desmuslin is an intermediate filament protein involved in smooth muscle function, and variants in its gene could be associated with VVs. In human smooth muscle cells (SMCs) from the saphenous vein, desmuslin knockdown using small interfering RNA (siRNA) causes increases in the synthesis of collagen and the expression of MMP-2, decreases in the expression of the SMC differentiation markers SM $\alpha$-actin, SMmyosin heavy chain and smoothelin, and disassembly of actin stress fibers. Desmuslin is important for preserving the VSMC contractile phenotype, and a reduction in desmuslin expression could cause VSMC phenotypic switch from contractile to synthetic phenotype, leading to weakening of the vein wall and the formation of $\mathrm{VVs}^{[48]}$.

Other genetic factors have been associated with advanced CVI, VLU and non-healed VLU, and include the genes for MMP-12, fibroblast growth factor receptor-2, hemochromatosis, factor XIII, and ferroportin [Table 1$]^{[36]}$. For instance, mutations in iron metabolism genes could be involved in VVs pathology. Prolonged venous reflux could cause iron overload and dermal hemosiderin deposition which is directly correlated with some of the manifestations of CVI such as lipodermatosclerosis and skin changes ${ }^{[49]}$. Iron deposition promotes free radical formation, thus aggravating tissue injury, and causing further progression to CVI and VLU ${ }^{[50,51]}$. Also, factor XIII is a cross-linking protein that is critical for VLU healing ${ }^{[52]}$, and mutations in hemochromatosis HFE gene $\mathrm{C} 282 \mathrm{Y}$ and Factor XIII gene V34L have been associated with severe CVI, skin changes and the size of VLU ${ }^{[53-55]}$.

\section{MMP LEVELS IN CVD}

Changes in MMP expression/activity have been described in VVs ${ }^{[1]}$. The levels of MMP-1, -2, -3, and -7 are elevated, and MMP-2 activity is increased in $\mathrm{VVs}^{[2]}$. Patients with primary VVs also show elevated plasma levels of MMP-10, the hemostatic markers prothrombin fragments 1 and 2, von Willebrand factor and ddimers, and increased activity of plasminogen activator inhibitor (PAI-1), which suggests a proinflammatory and prothrombotic state ${ }^{[56]}$. Studies have also shown increases in MMP-1 levels in the great saphenous vein and in the levels of MMP-1 and -13 in the proximal vs. distal regions of VVs, with no change in MMP mRNA expression, suggesting MMP post-transcriptional modification ${ }^{[57]}$. MMP levels also 
vary among different cell types in VVs. In VVs tissue sections, MMP-1 is localized in fibroblasts, VSMCs and endothelial cells; MMP-9 is mainly in endothelial cells, medial VSMCs and adventitial microvessels; and MMP-12 is detected in fibroblasts and VSMCs ${ }^{[58]}$. The localization of MMPs in fibroblasts and the tunica adventitia is in agreement with their role in degradation of ECM proteins, especially during the later stages and progression of VVs ${ }^{[58]}$. Other studies have found increases in MMP-1 expression in all layers of VVs, and MMP-9 expression in the intima and adventitia of VVs ${ }^{[15]}$. Studies also showed increases in MMP2 levels in all layers, and in MMP-1, -3 and -7 in the tunica intima and media of $\mathrm{VVs}^{[2]}$, which suggests potential effects of MMPs on the endothelium and VSMCs ${ }^{[58,59]}$.

While many studies showed increases in certain MMPs in VVs, some studies showed no change or even a decrease in MMP levels. One study reported a decrease in the levels of active MMP-1 and both the pro- and active forms of MMP-2 in $\mathrm{VVs}^{[60]}$. The variable MMPs levels may explain the variable collagen content in different regions of VVs showing a decrease ${ }^{[17]}$, no change ${ }^{[18]}$, or even an increase ${ }^{[16]}$. The variability in MMP levels could also be due to examining different regions of VVs, e.g., hypertrophic vs. atrophic regions at different anatomic locations, or examining vein segments at different stages of CVD progression, or inability to distinguish the proMMPs from active forms of MMPs.

MMP expression and activity could be associated with CVD progression and advanced stages of CVI. Serum levels of MMP-2, disintegrin and metalloproteinase with thrombospondin motif-1 (ADAMTS-1) and ADAMTS-7 are elevated during the initial stages of CVD development, while the serum levels of MMP$1,-8,-9$, neutrophil gelatinase-associated lipocalin (NGAL), ADAM-10 and -17 and ADAMTS- 4 are mainly elevated during advanced stages of CVD in association with skin changes ${ }^{[61]}$. MMP-1 and -8 expression is increased in the tissues and fluids of non-healing $\mathrm{VLU}^{[62]}$, and their levels are even higher in infected than uninfected VLU ${ }^{[63]}$.

\section{MMP INDUCERS/ACTIVATORS IN CVD}

MMPs can be induced or activated by multiple factors. Some factors could specifically regulate the mRNA expression or proteolytic activity of MMPs in VVs and include increased lower limb venous hydrostatic pressure, inflammation, hypoxia, and tissue metabolites.

\section{Venous hydrostatic pressure regulates MMPs in CVD}

An increase in lower limb venous hydrostatic pressure could increase MMP expression/activity and lead to VVs [Figure 2]. In vitro studies have demonstrated that mechanical stretch increases MMP expression in cultured endothelial cells, VSMCs and fibroblasts ${ }^{[64]}$. Our ex vivo studies have also shown that prolonged stretch of rat IVC causes an increase in MMP-2 and MMP-9 expression in the vein tunica intima and in MMP-9 expression in the vein media. Also, prolonged stretch of the rat IVC was associated with a decrease in the vein contraction to the $\alpha$-adrenergic receptor agonist phenylephrine, and MMP inhibitors reversed the effects of prolonged mechanical stretch on IVC contraction. These observations led us to hypothesize that prolonged increases in venous pressure or wall tension cause increases in MMP-2 and MMP-9 expression/activity, leading to decreased vein contraction and increased venous dilation ${ }^{[65]}$. The mechanisms linking the increased venous hydrostatic pressure to the increases in MMP expression could involve different intermediary biological steps including hypoxia inducible factors (HIFs), tissue metabolites and inflammation ${ }^{[6]}$.

\section{Hypoxia and MMPs in CVD}

HIFs are nuclear transcriptional factors that are triggered in response to tissue hypoxia, and in turn regulate many of the genes that control oxygen homeostasis. Mechanical stretch could also affect HIFs expression. 


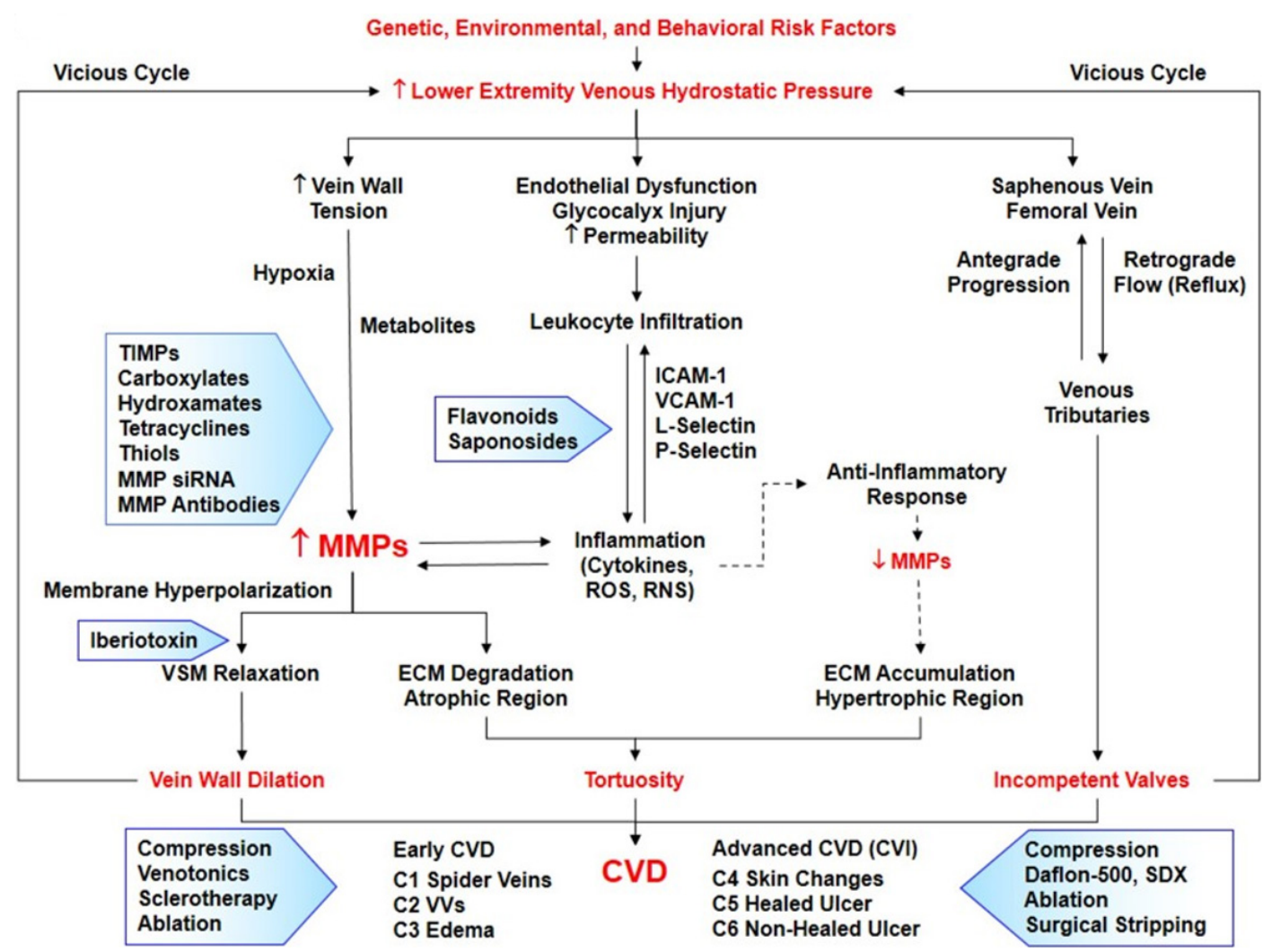

Figure 2. Pathophysiology and management of CVD. Genetic, environmental and behavioral risk factors cause an increase in HIFs and tissue metabolites leading to increases in MMPs. Increased venous hydrostatic pressure also causes changes in shear stress, endothelial dysfunction, glycocalyx injury, increased permeability, leukocyte infiltration, and increased adhesion molecules, inflammatory cytokines, ROS, and RNS, leading to further increases in MMPs. Increased MMPs cause VSM hyperpolarization and relaxation as well as ECM degradation leading to vein wall dilation, and progressive increases in venous hydrostatic pressure (vicious cycle). Increased MMPs generally promote ECM degradation particularly in atrophic regions. Other theories (indicated by interrupted arrows) suggest a compensatory anti-inflammatory pathway involving prostaglandins and their receptors that leads to decreased MMPs, ECM accumulation in hypertrophic regions, and tortuous VVs. Increased venous hydrostatic pressure in the lower extremity saphenous and femoral veins also causes venous valve dysfunction and venous reflux. Progressive vein wall dilation and valve dysfunction lead to different stages of CVD and CVI. Current treatment (presented in shaded arrows) includes compression stockings, venotonics and other pharmacological and surgical approaches. MMP inhibitors (also presented in shaded arrows) may provide potential tools for the management of CVD/CVI. CVD: Chronic venous disease; HIFs: hypoxia inducible factors; MMPs: matrix metalloproteinases; VSM: vascular smooth muscle; ECM: extracellular matrix; VVs: varicose veins; CVI: chronic venous insufficiency; TIMPs: tissue inhibitors of metalloproteinases; ICAM-1: intercellular adhesion molecule-1; VCAM-1: vascular cell adhesion molecule-1; siRNA: small interfering RNA; ROS: reactive oxygen species; RNS: reactive nitrogen species; SDX: sulodexide.

Prolonged stretch of rat skeletal muscle causes increases in HIF- $1 \alpha$ and $-2 \alpha$ mRNA expression and protein levels in the muscle capillaries' endothelial cells ${ }^{[67]}$. Also, in the rat heart, application of mechanical stretch to the ventricular wall promotes increases in HIF-1 $\alpha$ expression ${ }^{[68]}$. Our previous studies demonstrated that prolonged mechanical stretch of the rat IVC causes increases in mRNA expression and protein levels of MMP-2 and MMP-9 as well as HIF- $1 \alpha$ and $-2 \alpha$. The stretch-induced increases in the mRNA expression and protein levels of MMPs and HIFs were accompanied with a decrease in the contractile response of the rat IVC to phenylephrine. Of note, the IVC contractile response was reduced even further during pretreatment of the veins with dimethyloxallyl glycine (DMOG), an HIF stabilizer that inhibits HIF-prolyl hydroxylase and prevents HIF inactivation. On the other hand, HIF inhibitors such as echinomycin and U0126 prevented the decrease in IVC contraction in response to prolonged stretch, suggesting that HIF could provide an intermediary mechanism between the increase in venous hydrostatic pressure and the reduction in the vein contractile response [Figure 3] ${ }^{[66]}$. It is possible that mechanical stretch causes activation of $\mathrm{Ca}^{2+}$ 


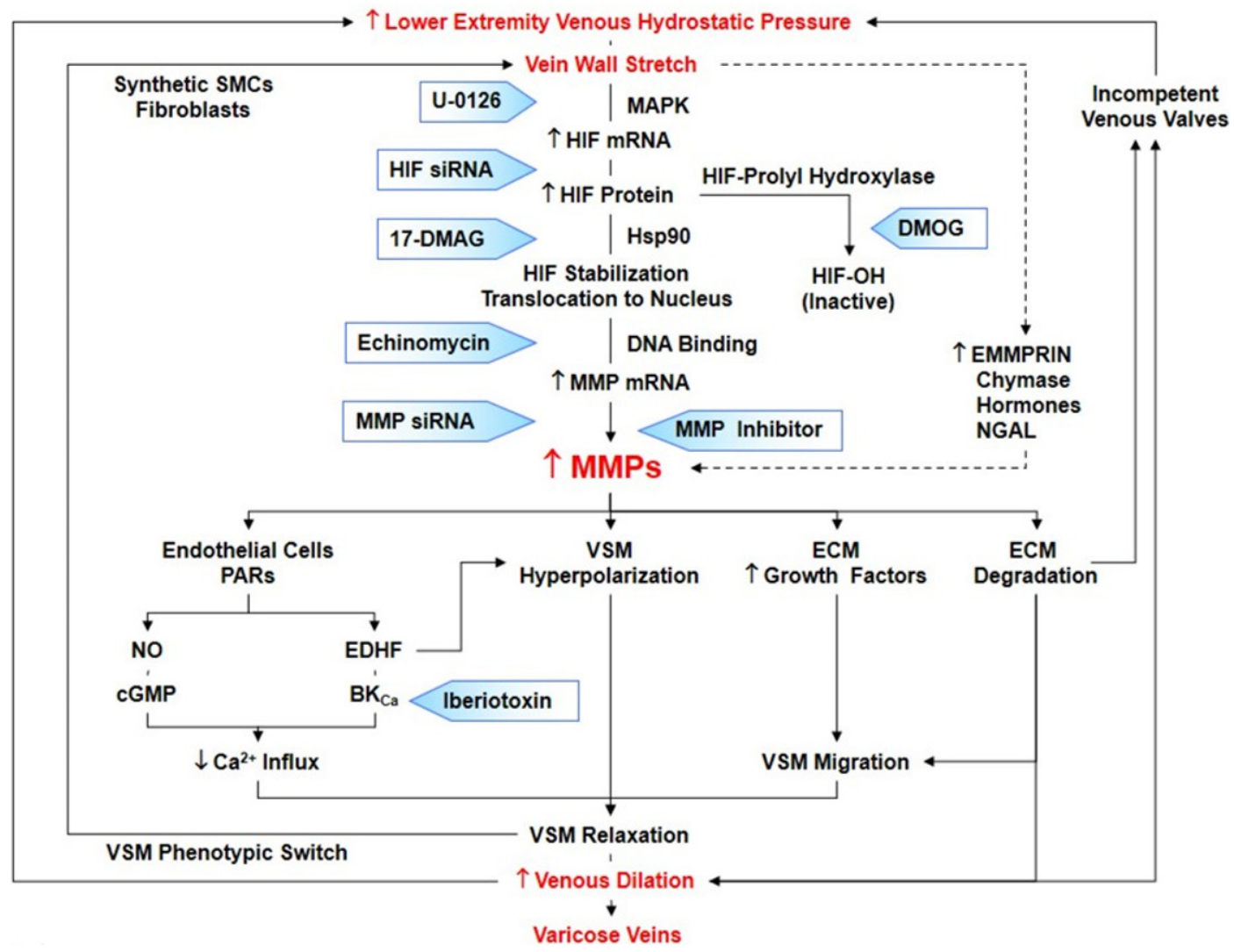

Figure 3. Mechanisms linking increased venous hydrostatic pressure to upregulation of MMPs in varicose veins. Increased lower extremity venous hydrostatic pressure causes vein wall stretch, increased HIF mRNA expression and protein levels, and increased MMP levels. Increased vein wall stretch could also increase other MMP inducers such as EMMPRIN, chymase, hormones and NGAL. Increased MMPs may activate PARs in endothelial cells leading to activation of NO-cGMP pathway or EDHF and BK $\mathrm{Ca}_{\mathrm{a}}$ channels in VSM, leading to hyperpolarization, decreased $\mathrm{Ca}^{2+}$ influx, and VSM relaxation. Prolonged loss of contractile function in VSM causes a phenotypic switch to synthetic VSMCs and increased propensity to stretch. MMPs may also increase the release of growth factors and cause ECM degradation leading to VSMC migration, further decreases in vein contraction and increases in venous dilation, and VVs. MMP-induced ECM degradation may also cause valve degeneration leading to further increases in venous hydrostatic pressure. As indicated in shaded arrows, inhibitors of MMP synthesis (U-0126, HIF siRNA, 17-DMAG, Echinomycin, MMP siRNA), activity (MMP inhibitor) or actions (Iberiotoxin) represent potential new tools for management of $\mathrm{VVs}_{\text {s. }} \mathrm{BK}_{\mathrm{Ca}}$ : Large conductance $\mathrm{Ca}^{2+}$-activated $\mathrm{K}^{+}$ channels; DMOG: dimethyloxallyl glycine, inhibitor of HIF-prolyl hydroxylase; HIF: hypoxia-inducible factor; Hsp90: heat shock protein 90. MAPK: mitogen-activated protein kinase. SMCs: smooth muscle cells; siRNA: small interfering RNA; MMP: matrix metalloproteinase; EMMPRIN: extracellular matrix metalloproteinase inducer; NGAL: neutrophil gelatinase-associated lipocalin; PARs: protease activated receptors; VSM: vascular smooth muscle; ECM: extracellular matrix; VSMCs: VSM cells; VVs: varicose veins.

entry via transient receptor potential vannaloid TRPV4 channel, leading to activation of phosphoinositide 3-kinase $\left(\mathrm{PI}_{3} \mathrm{~K}\right)$ and induction of $\mathrm{HIFs}^{[60]}$. It is also possible that mechanical stretch may affect membrane integrins and trigger a signaling cascade that eventually causes activation of mitogen-activated protein kinase (MAPK) and induction of HIF mRNA expression. Mechanical stretch may also stimulate G proteincoupled receptors (GPCRs) or tyrosine kinases or increase the production of reactive oxygen species (ROS), leading to MAPK activation and increased HIF expression. We have shown that MAPK inhibitors reverse the increases in mRNA expression of HIFs and the decreases in contraction in IVC segments under prolonged mechanical stretch, which supports a role of MAPK as signal transduction pathway linking mechanical stretch, HIF expression and vein contraction $^{[6]]}$. 
Other observations support the contention that HIF is involved in the pathogenesis of CVD. For instance, HIF- $1 \alpha$ and $-2 \alpha$ mRNA expression and the HIF-activated target genes are increased in VVs ${ }^{[70]}$. HIF- $1 \alpha$ may also regulate MMP-2 and MMP-9 expression in arterio-venous fistulas and hemodialysis polytetrafluoroethylene grafts ${ }^{[7]}$. Besides mechanical stretch, additional factors including low $\mathrm{pH}$, low oxygen tension, metallic ions, heat exposure, and hormones could affect the expression of HIFs and MMPs in lower extremity veins.

\section{Tissue metabolites in CVD}

Increased venous tissue metabolism and increased generation of ROS and tissue metabolites could also play a role in CVD. Metabolic profiling and metabolomic approaches have shown increased concentration of lactate, creatine and myo-inositol metabolites in VVs samples as compared to non-varicose control veins ${ }^{[72]}$. Also, using a metabolomic approach, Dr. Alun Davies' research group in collaboration with our group have shown increases in the levels of triglyceride moieties and choline and valine metabolites in association with decreased contraction in IVC segments under prolonged stretch compared with veins under normal control basal tension, supporting that increased vein wall tension/venous pressure could alter the tissue metabolic profile in the setting of $\mathrm{VVs}^{[73]}$. Whether the increases in tissue metabolites affect the vein tissue expression of HIFs and MMPs and in turn affect vein contraction remains to be examined.

\section{Inflammation and MMPs in CVD}

Increases in venous hydrostatic pressure in the lower extremities could also cause injury to the vein endothelium, damage to the glycocalyx, increases in the permeability of endothelial cells, activation of adhesion molecules, infiltration of leukocytes and inflammation of the vein ${ }^{[74]}$. Altered shear stress could lead to injury to the glycocalyx, endothelial dysfunction and progression of CVD. The glycocalyx structure is markedly altered and is associated with increased inflammation in CVD and $\mathrm{VVs}^{[75]}$. The glycocalyx is composed of glycoproteins with acidic oligosaccharides and terminal sialic acid, proteoglycans (heparan sulfate proteoglycan, syndecans and glypican core proteins), and glycosaminoglycan side chains that are sulfated (chondroitin sulfate, dermatan sulfate, heparan sulfate, keratan sulfate, and heparin), and nonsulfated (hyaluronic acid). The most common glycoasaminoglycans found on the glycocalyx are heparan sulfate, chondroitin sulfate, and hyaluronic acid ${ }^{[76,77]}$. The glycocalyx has important functions including mediating mechanotransduction, sense changes in shear stress, selective permeability, electrostatic barrier to cells and proteins, anti-coagulation barrier, anti-inflammatory, anti-adhesive, and counteracting endothelial injuries induced by the hemodynamics ${ }^{[77]}$. Several models have determined the effect of shear stress on glycocalyx expression (heparan sulfate proteoglycan, syndecan family and glypican-1) on endothelial cells, and their role in vascular dysfunction ${ }^{[78]}$. Other models in rat venous mesentery have demonstrated that reducing shear stress has a marked effect on activation of leukocytes and adhesion, inflammatory molecules, and MMPs expression. Human leukocytes also have similar behavior with respect to low shear stress ${ }^{[79,80]}$. Rat models of increased hind limb venous pressure induced by a femoral arterio-venous fistula, show increased saphenous vein venous pressure, upregulation of P-selectin and intercellular adhesion molecule-1 (ICAM-1), infiltration of leukocytes, and inflammation of the vein wall ${ }^{[81]}$. Leukocytes are an important source of $\mathrm{MMPs}^{[82]}$, and the activation of adhesion molecules and subsequent adhesion and infiltration of leukocytes in the vein wall could augment the production and release of MMPs. Subsequently, MMPs degrade different substrates in ECM, leading to weakening of the vein wall, decrease in the vein contraction, venous dilation, valve incompetence, further increases in the lower extremity venous hydrostatic pressure, and progression of CVD [Figure 2] ${ }^{[4]}$. The relationship between increased lower limb venous hydrostatic pressure, inflammation of the vein wall, increased release of MMPs and degradation of ECM proteins is typically observed in the VVs atrophic regions. 
In support of a role of inflammation in CVD, segments of saphenous vein obtained from VVs patients show increased monocyte/macrophage infiltration in the vein wall and valves ${ }^{[2,83]}$, and increased expression of ICAM-1 and vascular cell adhesion molecule-1 (VCAM-1) in endothelial cells ${ }^{[84]}$. VVs patients also show increases in the plasma levels of the inflammatory markers ICAM-1, VCAM-1, angiotensin converting enzyme, and L-selectin in association with increases in plasma proMMP-9 levels, supporting a relationship between postural blood stasis, increased lower limb venous hydrostatic pressure, infiltration of polymorphonuclear leukocytes in the vein wall, and increased MMP release in VVs ${ }^{[85]}$.

Proinflammatory cytokines may contribute to the inflammation of the vein wall and the increases in the release of MMPs. Urokinase plasminogen activator ( $\mathrm{uPA}$ ) contributes to the inflammation process by increasing tumor necrosis factor- $\alpha$ (TNF- $\alpha$ ) expression in injured vessels. TNF- $\alpha$ increases MMP-9 gene promoter activity via activation of specificity protein-1 (Sp-1), activator protein-1 (AP-1), and nuclear factor $\kappa$ light chain enhancer of activated B cells $(\mathrm{NF}-\kappa \mathrm{B})^{[86]}$. Also, interleukins such as IL-17 and IL -18 induce MMP-9 mRNA expression through activation of signaling pathways involving AP- 1 and NF- $\mathrm{KB}^{[87]}$. Of note, patients with infected VLU show greater levels of TNF- $\alpha$, IL-1, IL-6, and IL-8, MMP-1 and MMP-8, and vascular endothelial growth factor (VEGF) compared to patients with non-infected VLU, supporting an association between inflammation, cytokine secretions, and MMP activation in advanced CVD and CVI ${ }^{[63]}$.

Cytokines could also increase ROS which consequently affect the expression and activity of MMPs. MMP expression is regulated by NADPH oxidase-1 (Nox-1) in fibroblasts ${ }^{[88]}$. Also, uPA affects the expression of MMP-9 in part through increasing ROS production ${ }^{[89}$. ROS could activate MMPs through oxidation of the MMP prodomain thiol and its autolytic cleavage. ROS may also modify the critical amino acids required for MMP proteolytic activity and lead to MMP inactivation, thereby providing a feedback-mechanism that controls any undesirable bursts in MMP activity ${ }^{[90]}$. Recent evidence also suggests the importance of reactive nitrogen species (RNS) in CVD. Peroxynitrite (ONOO) is a potent oxidizing and nitrating agent that causes damage to the mitochondria, DNA, lipids via peroxidation, and protein oxidation and nitration, leading to post-translational modifications of many proteins, enzyme inactivation, and destruction of cellular functions. Specifically, ONOO- inhibits superoxide dismutase (SOD), causing further increases in ROS generation and activation of MMPs. A recent study of VLU tissue showed markedly elevated oxidative stress markers (increased lipid peroxidation, gluthathione activity, and radical scavenging activity), and tissue injury (as indicated by elevated lactate dehydrogenase). There were also marked increases in the levels of poly ADP ribose, an indicator of DNA damage/repair, as well as elevated levels of nitrotyrosine, a stable byproduct of $\mathrm{ONOO}^{-}$activity. This study was one of the first to demonstrate the presence and activation of poly ADP ribose and $\mathrm{ONOO}^{-}$in $\mathrm{CVD}^{[1]}$. Further investigations are needed to determine if $\mathrm{ONOO}^{-}$is also present in VVs, and consequently develop treatment strategies to reduce $\mathrm{ONOO}^{-}$formation.

\section{Other MMP inducers/activators in CVD}

Other MMP inducers and activators could increase MMP expression and activity in VVs. For instance, extracellular MMP inducer, also known as extracellular matrix metalloproteinase inducer (EMMPRIN), Basigin or CD147, is a membrane protein and a member of the immunoglobulin superfamily that is widely expressed and involved in the remodeling of many tissues and in the pathophysiology of many conditions including atherosclerosis, vascular aneurysm, cardiac failure, rheumatoid arthritis, and cancers. High volume mechanical ventilation could cause acute injury of the lung, and could promote increases in the expression of MMPs such as MMP-2, MMP-9, and MT1-MMP as well as EMMPRIN ${ }^{[2]}$. MMP-2, MT1MMP, MT2-MMP and EMMPRIN are also upregulated in dermal structures of VLU, causing uncontrolled increase in MMP activity and further increases in ECM degradation ${ }^{[93]}$. 
Vascular cells also produce bioactive lipid metabolites and prostanoids that could affect MMP activity in CVD and VVs. Prostaglandin-E2 (PGE2) through activation of EP1-4 receptors play a role in the regulation vascular tone, vascular wall remodeling and tissue inflammation ${ }^{[94]}$. In human endometriotic stromal and epithelial cells, PGE2-induced stimulation of EP2 and EP4 receptors causes increases in the activity of $\mathrm{MMP}^{[95]}$. Of note, the synthesis of PGE2 may decrease in CVD and VVs owing to compensatory increases in the anti-inflammatory 15-deoxy-delta-12,14-PGJ2, decreases in membrane-associated PGE-synthase-1, and increases in the 15-hydroxyprostaglandin dehydrogenase enzyme degradation activity. A decrease in PGE2 levels and in turn reduction in EP4 receptor activity could lead to a decrease in the activity of MMP-1 and MMP-2 activity, resulting in increased collagen accumulation that is mainly observed in the hypertrophic regions of VVs [Figure 2] ${ }^{[60]}$.

Chymase, a chymotrypsin-like serine protease produced by mast cells and the cardiovascular system, has been associated with the increases in MMP-9 activity and the infiltration of monocytes and macrophages in the aortic wall of stroke-prone spontaneously hypertensive rats ${ }^{[96]}$. Estrogen and progesterone increase the expression and activity of MMP-2 and MMP-9 in blood vessels, the uterus and placenta ${ }^{[97,98]}$. Also, NGAL binds to and protects MMP-9 from degradation by proteolytic enzymes, and leads to increases in its levels/activity ${ }^{[99]}$. Whether these MMP inducers and activators are upregulated in CVD and VVs needs to be explored.

\section{MMP ACTIVITIES IN CVD}

MMPs are largely known for their ability to cause proteolysis of different substrates and to promote degradation of various ECM proteins, which could contribute to venous tissue remodeling and the pathogenesis of VVs. Additionally, MMPs could affect other molecular and signaling pathways in VSMCs and endothelial cells and consequently affect vein function, particularly in the initial vasodilation stages of CVD.

\section{MMPs and ECM degradation in CVD}

Alterations in MMP activity affect ECM composition and contribute to the abnormalities in vein structure and function associated with CVD. While many studies have shown that MMP levels are increased in VVs, some reports show that MMP levels could be decreased in $\mathrm{VVs}^{[60]}$. The discrepancy in the levels of MMPs may in part explain the structural and pathological differences observed in the atrophic vs. hypertrophic regions of VVs. Increases in the activity of MMPs are expected to cause degradation of ECM proteins mainly in the atrophic regions of $\mathrm{VVs}^{[14]}$. Conversely, decreased MMP activity would preserve and cause accumulation of ECM proteins in the hypertrophic regions of VVs, thus interfering with the contractility of VSMCs, and leading to reduction in the vein contractile function and increased venous dilation in VVs ${ }^{[100]}$.

MMPs could affect the ECM content of collagen and elastin. VVs show increased collagen type-I and decreased collagen type-III compared with control veins ${ }^{[19,101,102]}$. Cultured VSMCs from VVs also show decreased collagen type-III and fibronectin possibly due to proteolytic degradation induced by MMP-3 ${ }^{[19]}$. VVs may also demonstrate a decrease in their elastin content possibly due to increased elastolytic degradation by MMPs or other proteases and elastases produced by fibroblasts, platelets, macrophages and monocytes ${ }^{[20]}$. The net amount of collagen and elastin in VVs is influenced by the dynamic interaction between different biological processes at different stages of CVD. For example, increases in the vein collagen content could compensate for the decreases in elastin levels during the early stages of CVD. Conversely, the vein collagen content may show a decrease in the later stages of VVs. This may provide an explanation for the divergent reports of the collagen levels in VVs, showing a decrease ${ }^{[17]}$, no change ${ }^{[18,20]}$ or even an increase $^{[16]}$. VVs may also show changes in other ECM proteins including increases in the levels of tenascin 
and decreases in the vein laminin levels ${ }^{[19,101,102]}$.

\section{MMPs and VSMC dysfunction in CVD}

Besides the MMP-induced changes in ECM proteins, MMPs could participate in the pathophysiology of CVD by influencing VSMC migration, growth, apoptosis and contractile function [Figure 3].

MMP-mediated ECM proteolysis modulates cell-matrix adhesion and in turn facilitates VSMC migration. MMP-1 and - 9 can mediate increases in human aortic SMC migration ${ }^{[103,104]}$. In rat aortic SMCs, upregulation of MMP-1 increases flow-mediated cell motility through phosphorylation of $\mathrm{ERK}_{1 / 2}$ and increases in c-Jun and c-Fos transcription factors ${ }^{[103]}$. In cultured human VSMCs, MMP-2 affects chemokine-induced chemotaxis ${ }^{[105]}$. Also, in mouse model of carotid artery ligation, MMP-2 knockout reduces SMC migration and neointima formation ${ }^{[106,107]}$. Similarly, MMP-9 promotes SMC migration, and MMP-9 knockout in mouse models of filament loop injury and carotid artery occlusion reduces SMC migration and intimal hyperplasia ${ }^{[108,109]}$.

MMPs disrupt the basement membrane, facilitate the interaction between ECM and integrins, and promote activation of focal adhesion kinases (FAK) and SMC migration ${ }^{[110]}$. MMPs also cause fragmentation of basement membrane proteins such as collagen type-I, thus uncovering new integrin-binding sites. In preparation for cell migration, integrins, cadherins and growth factor receptors coordinate their functions in order to reorganize the cytoskeleton ${ }^{[11,112]}$. MMPs cleave E-cadherin in epithelial cells, VE-cadherin in endothelial cells and N-cadherin in VSMCs ${ }^{[113,114]}$, thus dissolving adherence junctions and allowing the cells to migrate. In addition to facilitating cell migration by promoting ECM proteolysis, MMP-1 binds to and cleaves protease-activated receptor-1 (PAR-1) and in turn uncovers tethered ligands that stimulate cell signaling and migration ${ }^{[15]}$. By sensing a proteolytic environment, the cells then actively and gradually move to the area where ECM is degraded.

SMC reorganization and migration into the vein intima may occur in $\mathrm{CVD}^{[116-119]}$. SMCs in VVs appear disorganized, dedifferentiated, and show vacuolization and phagocytosis ${ }^{[116,117]}$. Compared to the VSMC contractile phenotype in healthy veins, VSMCs isolated from VVs are largely dedifferentiated and show increased MMP-2 secretory potential and tendency for migration ${ }^{[120]}$. MMP-mediated SMC dedifferentiation and migration lead to phenotypic switch from contractile to synthetic phenotype, decreases in the vein contractile response and further venous dilation [Figure 3].

MMPs also facilitate a growth-permissive environment between VSMCs and ECM through integrinmediated signaling ${ }^{[121]}$. MT1-MMP stimulates the release of transforming growth factor- $\beta$ (TGF- $\beta$ ) and facilitates maturation of osteoblasts ${ }^{[122]}$. Also, MMP-2 upregulation increases, while downregulation of MMP-2 decreases VEGFa expression in human gastric cancer cell line ${ }^{[123]}$. MMPs also facilitate the release of growth factors from their binding proteins, which may promote VSMC hypertrophy in the hypertrophic regions of $\mathrm{VVs}^{[124]}$.

The contacts between the cells and ECM enhance VSMC survival, and disruption of these cell-ECM contacts causes apoptosis and anoikis (programmed cell death of anchored cells when they become detached from ECM ${ }^{[125]}$. ECM-integrin interactions activate FAK and induce the p53 signaling pathway and cell survival ${ }^{[126,127]}$. Normal MMP levels are required for FAK activation and induction of the cell survival signaling pathway, but if MMP production becomes excessive it could cause increases in the degradation of ECM proteins and integrins and lead to anoikis ${ }^{[128]}$. For instance, MMP-7 cleaves $\mathrm{N}$-cadherin and in turn regulates apoptosis of VSMCs. MMPs could also regulate apoptosis by cleaving the death ligands TNF- $\alpha$ 
and Fas and their receptors. MMP-1, -2, - 8, -9, -13, -14 and -17 cleave the TNF- $\alpha$ precursor pro-TNF- $\alpha$ into its active form ${ }^{[129,130]}$. Also, MMP-7 cleaves Fas-L leading to its shedding from the cell surface ${ }^{[131,132]}$. MMP-2 has been localized in the nucleus of isolated cardiac myocytes, where it promotes caspase-dependent cleavage of the DNA repairing enzyme poly-ADP ribosepolymerase and leads to cell apoptosis ${ }^{[133]}$. While MMPs regulate cell apoptosis, the contribution of SMC apoptosis to VVs pathology needs to be further examined.

Besides the tunica adventitia and ECM, the localization of MMPs in the tunica intima and tunica media suggests additional effects on endothelial cells and VSMCs ${ }^{[8,59]}$. In rat mesenteric arteries, MMP-2 and -7 through $\mathrm{PI}_{3} \mathrm{~K}$ activation and ATP synthesis cause transactivation of epidermal growth factor receptor and maintain phenylephrine-induced vascular tone. In support, MMP-2 or -7 knockdown by siRNA blunts Akt phosphorylation of $\mathrm{PI}_{3} \mathrm{~K}$ in rat aortic VSMCs ${ }^{[134]}$. On the other hand, MMP-2 and MMP-9 inhibit phenylephrine-induced contraction in rat aortic segments in a time-dependent, concentration-dependent, and reversible fashion, which suggests that the MMP effects are not caused by irreversible proteolysis and degradation of ECM protein components ${ }^{[135]}$. Also, the MMP-induced inhibition of the VSM contractile response may not be due to destruction of the phenylephrine molecule or proteolytic degradation of the $\alpha$ adrenergic receptors because MMPs also inhibit vascular contraction induced by prostaglandin F2 $\alpha$, and these observations can be interpreted as direct effects of MMPs on a common post-receptor VSMC contraction mechanism. VSMC contraction is initiated by $\mathrm{Ca}^{2+}$ release from the sarcoplasmic reticulum and maintained by $\mathrm{Ca}^{2+}$ influx through plasma membrane channels. Our previous studies have shown that MMP-2 and MMP-9 do not affect phenylephrine-induced contraction in rat aortic segments incubated in $\mathrm{Ca}^{2+}$-free solution, suggesting that MMPs do not affect the $\mathrm{Ca}^{2+}$ release mechanism from the sarcoplasmic reticulum ${ }^{[135]}$. Importantly, MMP-2 and MMP-9 inhibit $\mathrm{Ca}^{2+}$ influx in rat aortic segments ${ }^{[135]}$, and MMP-2 inhibits extracellular $\mathrm{Ca}^{2+}$-dependent contractile response in rat $\mathrm{IVC}^{[136]}$. It could be argued that MMPs induce protein degradation and in turn produce Arg-Gly-Asp (RGD)-containing peptides, which could bind to $\alpha_{v} \beta_{3}$ integrins and lead to inhibition of $\mathrm{Ca}^{2+}$ influx into VSMCs ${ }^{[137]}$. This may be unlikely because our experiments with RGD peptides showed that they did not inhibit the IVC contractile response $\mathrm{e}^{[136]}$. One possibility is that MMPs could activate PARs and their downstream signaling pathways leading to blockade of $\mathrm{Ca}^{2+}$ channels in $\mathrm{VSMCs}^{[138]}$. In support, thrombin acts as a protease and activates PARs, consequently promoting endothelium-dependent inhibition of $\mathrm{Ca}^{2+}$ influx and relaxation of $\mathrm{VSMCs}^{[139]}$. We have previously reported that the relaxation of rat IVC segments induced by MMP-2 is prevented in veins incubated in a high $\mathrm{KCl}$ depolarizing solution, which blocks outward movement of $\mathrm{K}^{+}$ion via plasmalemmal $\mathrm{K}^{+}$channels. Also, iberiotoxin, a blocker of large-conductance $\mathrm{Ca}^{2+}$-activated $\mathrm{K}^{+}$channels $\left(\mathrm{BK}_{\mathrm{C}}\right)$, inhibited MMP-2 induced relaxation of rat IVC, which suggests that MMP-2 actions involve membrane hyperpolarization, activation of $\mathrm{BK}_{\mathrm{Ca}}$ and inhibition of $\mathrm{Ca}^{2+}$ entry through voltage-dependent $\mathrm{Ca}^{2+}$ channels [Figure 3] ${ }^{[140]}$. Long-term, maintained MMP-induced inhibition of $\mathrm{Ca}^{2+}$ entry and the vein contractile response could lead to progressive venous dilation and formation of VVs.

\section{MMPs and endothelial integrity and function}

VVs often show inflammatory cell infiltration and increased ICAM-1 and VCAM-1 expression ${ }^{[57,84,116]}$, and these effects could be related to changes in MMP expression. MMPs regulate endothelial integrity and vascular permeability. Application of supernatants from cultured colon cancer and melanoma cells on human umbilical endothelial cells (HUVECs) and human dermal microvascular endothelial cells renders the cells a more prothrombotic, proinflammatory, and cell-adhesive state through activation of MMP1/PAR-1 pathway ${ }^{[141]}$. In mouse aorta, MMP-13 induced cleavage of ICAM-1 may require endothelial nitric oxide synthase $\mathrm{e}^{[142]}$. Upregulation of MMP-2 and MMP-9 plays a role in the increases in vascular permeability and membrane disruption induced by human immunodeficiency virus- 1 in rat brain ${ }^{[143]}$. MMP-2 and MMP-9 also disrupt membrane barrier integrity in porcine brain capillary endothelial cells ${ }^{[144]}$, 
and the MMP inhibitor GM6001 prevents degradation of the tight junction protein occludin and reduces the intercellular gap and vascular permeability in porcine cerebral microcapillary endothelial cell $\mathrm{s}^{[145]}$. Endothelial cells regulate vascular tone by releasing NO, prostacyclin $\left(\mathrm{PGI}_{2}\right)$ and endothelium-derived hyperpolarizing factor $(\mathrm{EDHF})^{[146]}$. Also, MMPs could activate PARs, and in turn contribute to venous dilation in CVD [Figure 3]. PARs 1-4 are GPCRs that have been found in humans and other species. PAR-1 is expressed in endothelial cells, VSMCs ${ }^{[147]}$, and platelets ${ }^{[148]}$ and is coupled to increased NO production ${ }^{[149]}$. MMP-1 activates PAR-1 ${ }^{[115]}$, which could contribute to progressive venous dilation and VVs formation.

EDHF causes vascular relaxation through the opening of small and intermediate conductance $\mathrm{Ca}^{2+}$-activated $\mathrm{K}^{+}$channels and endothelial cell hyperpolarization. The hyperpolarization of endothelial cells then spreads through myoendothelial gap junctions and causes VSM relaxation. EDHF-mediated vascular relaxation may involve epoxyeicosatrienoic acids, which are produced from the metabolism of arachidonic acid by cytochrome $\mathrm{P} 450$ epoxygenases. Other EDHFs include $\mathrm{K}^{+}$ion and hydrogen peroxide $\left(\mathrm{H}_{2} \mathrm{O}_{2}\right)^{[140]}$. EDHF could then open $\mathrm{BK}_{\mathrm{Ca}}$ and cause hyperpolarization of $\mathrm{VSMCs}^{[146]}$. Our studies in rat IVC have suggested that MMP-2 could increase EDHF release and promote $\mathrm{K}^{+}$efflux via $\mathrm{BK}_{\mathrm{Ca}}$, which in turn causes vein hyperpolarization and relaxation ${ }^{[140]}$. On the other hand, studies suggest that MMP-3 may impair endothelium-dependent vasodilation ${ }^{[150]}$, and therefore it is important to further study the effects of MMPs on the endothelium and vascular relaxation mechanisms.

\section{MANAGEMENT OF CVD}

Treatment of CVD includes conservative approaches and venotonics in the early stages, and interventional surgical approaches in more advanced stages [Table 2]. MMP inhibitors have also been considered as potential approaches for management of CVD.

\section{Conservative approaches for CVD}

VVs can first be managed using physical approaches such as graduated elastic compression stockings, which promote venous emptying, decrease pain and edema, and could slow VVs progression to the more advanced forms of CVI presented as skin changes and VLU ${ }^{[151,152]}$. Compression elastic stockings could also help to reduce the incidence of venous thromboembolism after VVs surgical procedures, and improve the hemodynamics in post-thrombotic syndrome $e^{[153]}$.

\section{Venotonic therapy for CVD}

Venotonic drugs could enhance venous tone, improve capillary permeability, and decrease leukocyte infiltration in the vein wall. Venotonics include $\alpha$-benzopyrones (coumarins), $\gamma$-benzopyrones (flavonoids), plant extracts (blueberry and grape seed, ergots, and Ginkgo biloba), saponosides (Centella asiatica, escin, horse chestnut seed extract, and ruscus extract $)^{[154]}$, and other naturally occurring compounds such as catechin (green tea), escletin, hesperitin, hesperidine, oxerutin, quercetin, rutosides, troxerutin, umbelliferone and venoruton ${ }^{[155]}$.

Flavonoids affect endothelial permeability and leukocyte infiltration and decrease edema and inflammation, and saponosides reduce vein wall distensibility and morphologic changes. Flavonoids such as diosmin and saponosides such as Aesculus hippocastanum, aescin, and escin have been used in the management of VVs and $V_{L U}{ }^{[156,157]}$. Diosmin, the active ingredient in Daflon-500, could improve venous tone, microcirculatory flow, microvascular permeability and lymphatic activity ${ }^{[15,158,159]}$. Escin could reduce leg edema, pain, and fatigue/heaviness, and decrease calf itching and cramp $^{[160,161]}$. Escin exerts its venotonic action through several mechanisms including improved permeability of endothelial cells, release of endothelium-derived vasoconstrictors such as prostaglandin-F2 $\alpha$, and vein sensitization to the contractile actions of histamine 
Table 2. Management of varicose veins

\begin{tabular}{|c|c|c|}
\hline Treatment strategy & Specific treatment & Ref. \\
\hline Compression therapy & $\begin{array}{l}\text { Graduated compression stockings, velcro compression, inelastic garments, multilayer } \\
\text { bandaging, short-stretch bandages }\end{array}$ & {$[152]$} \\
\hline $\begin{array}{l}\text { Pharmacological } \\
\text { treatment }\end{array}$ & $\begin{array}{l}\alpha \text {-benzopyrones (Coumarins) } \\
\gamma \text {-benzopyrones (Favonoids) } \\
\text { Saponosides (Escin, horse chestnut seed extract) } \\
\text { Plant extracts (Blueberry and grape seed, Ginkgo biloba) } \\
\text { Daflon-500 } \\
\text { Venoruton (Oxerutin) } \\
\text { Others: Pentoxifylline, red vine leaves (AS-195), prostaglandin E1 }\end{array}$ & $\begin{array}{l}{[154]} \\
{[155]} \\
{[156,157,163]} \\
{[242]} \\
{[156,158,159,243]} \\
{[170]} \\
{[244-246]}\end{array}$ \\
\hline Sclerotherapy & Sodium tetradecyl sulfate, sodium morrhuate and polidocanol & {$[172,247]$} \\
\hline Surgical intervention & $\begin{array}{l}\text { Endovenous ablation (Radiofrequency or infrared laser) } \\
\text { Surgical stripping } \\
\text { Ambulatory micro-phlebectomy, transilluminated power phlebectomy }\end{array}$ & $\begin{array}{l}{[174-176]} \\
{[177]} \\
{[178]}\end{array}$ \\
\hline
\end{tabular}

and serotonin ${ }^{[157,162,163]}$. Escin is also known to form small pores in the cell plasma membrane and is utilized experimentally to examine the sensitivity of the vascular contraction pathways to various vasoconstrictor agonists, and for permeabilization or skinning of VSMC membrane in order to change critical intracellular ions or regulatory proteins ${ }^{[157,163-165]}$. Escin-induced pores permit $\mathrm{Ca}^{2+}$ and other biologically-relevant factors ( $>3000$ dalton) including calmodulin and heparin to diffuse across the plasma membrane without damaging membrane receptors or coupling mechanisms ${ }^{[166]}$. On the other hand, diosmin may increase lymph drainage, decrease vein inflammation, and inhibit venous cathecol-O-methyltransferase (COMT) and in turn decrease norepinephrine metabolism and prolong its effects on vein constriction ${ }^{[167,168]}$. Some studies also suggest that diosmin may enhance the venotonic effects of $\operatorname{escin}^{[164]}$. Our recent studies have examined the effects of escin and diosmin in rat $\mathrm{IVC}^{[169]}$. In $\mathrm{Ca}^{2+}$-free solution, escin did not cause IVC contraction. In veins pretreated with escin in a $0 \mathrm{Ca}^{2+}$ incubation solution, gradual increases in extracellular $\mathrm{CaCl}_{2}$ were associated with stepwise increases in the vein contractile response. In escin-pretreated rat IVC, the contraction to phenylephrine, AngII and high $\mathrm{KCl}$ was reduced. In comparison, diosmin caused small IVC contraction in normal or $\mathrm{Ca}^{2+}$-free solution. In rat IVC pretreated with diosmin in a $0 \mathrm{Ca}^{2+}$ incubation solution, gradual increases in extracellular $\mathrm{CaCl}_{2}$ caused negligible contraction. Diosmin did not augment the IVC contractile response to phenylephrine, AngII or escin, but increased the vein contraction in response to high $\mathrm{KCl}$ solution. These observations in rat IVC suggested that escin promotes extracellular $\mathrm{Ca}^{2+}$-dependent venous contraction, but disrupts $\alpha$-adrenergic receptor- and angiotensin receptor-mediated contraction mechanisms. Thus, the initial extracellular $\mathrm{Ca}^{2+}$-dependent venotonic benefits of escin could be offset by its disruption of the vein contractile response to various endogenous venoconstricting factors, which would limit its long-term usefulness in pharmacological treatment of VVs. Also, diosmin does not appear to promote vein contraction on its own or enhance the venotonic effects of escin or endogenous venoconstricting factors, and therefore its benefits as a venotonic agent need further examination ${ }^{[169]}$.

In patients with advanced CVI, rutosides have shown some enhancement of endothelial cell function ${ }^{[170]}$. Also, pentoxifylline, a xanthine derivative that has anti-inflammatory and hemorheologic effects such as TNF- $\alpha$ inhibition, decreased synthesis of leukotrienes, and reduced deformability of red blood cells, may have benefits in advanced $\mathrm{CVI}^{[171]}$. PGE1 and red vine leaves (AS 195) may also improve microcirculatory blood flow and transcutaneous oxygen tension leading to reduction of leg edema in $\mathrm{CVI}^{[4]}$.

\section{Surgical approaches for CVD}

Several strategies can be used to obliterate the engorged VVs and improve the venous hemodynamics. Sclerotherapy under the guidance of Duplex ultrasound involves administration of hypertonic solutions of saline or high concentrations of sclerosing compounds such as ethanolamine oleate or sodium morrhuate in 
the dilated VVs. Other sclerosing agents approved by the Food and Drug Administration (FDA) include the liquid detergent sodium tetradecyl sulfate (STS) and polidocanol ${ }^{[172]}$. STS and polidocanol produce foam that displaces blood, and causes vasoconstriction and eventually thrombosis and occlusion of VVs. VVs patients treated with proprietary polidocanol endovenous microfoam have reported good benefits and improved quality of life ${ }^{[173]}$.

Other surgical approaches include endovenous ablation with a radiofrequency or infrared laser at wavelengths ranging between 810 and $1320 \mathrm{~nm}$, but could be as high as 1470 and $1550 \mathrm{~nm}$. The high endovenous heat denatures endothelial cell proteins and occludes $\mathrm{VVs}^{[174]}$. Ablation therapy has shown acceptable vein occlusion rates, good clinical outcomes, and $\sim 2 \%$ vein recanalization rate 4 years following radiofrequency therapy ${ }^{[175]}$ and only 3\%-7\% VVs recurrence rate 2-3 years following infrared laser therapy ${ }^{[176]}$. Stripping of the saphenous vein and high ligation of the saphenofemoral junction are also commonly used surgical approaches with a low VVs recurrence rate ${ }^{[177]}$. Ambulatory micro-phlebectomy involves avulsion of clusters of large VVs and incompetent saphenous vein. Transilluminated power phlebectomy is also used to remove clusters of VVs through fewer incisions and a shorter surgical procedure $^{[178]}$.

Innovative endovenous treatment of VVs involves the use of non-thermal and non-tumescent approaches including cyanoacrylate glue and related mechanochemical techniques ${ }^{[179,180]}$. Initial clinical outcomes are promising, but further studies are needed to evaluate the potential benefits of these new approaches $v s$. the thermal ablation and surgical procedures.

\section{SDX in venous leg ulcer}

SDX is a highly-purified glycosaminoglycan with antithrombotic and profibrinolytic effects, which has shown benefits in atherosclerotic and thrombotic vascular disease. SDX-mediated decrease in blood viscosity together with its fibrinolytic and lipolytic properties has made it beneficial in vascular disorders such as atherosclerotic peripheral arterial disease, chronic leg ischemia, post-thrombotic venous syndrome, and venous thromboembolism ${ }^{[181-186]}$. SDX has also shown some benefits in diabetic microangiopathy and nephropathy, advanced CVI and VLU ${ }^{[182,185,187]}$. Experimental studies have also shown beneficial actions of SDX including reduction of oxidative stress ${ }^{[188]}$, modulation of growth factors, decreased MMP expression, reduced inflammation, anti-angiogenic effects ${ }^{[189]}$, and protection of endothelial cells ${ }^{[14,75,190-195]}$.

Recent studies have shown that in CVD patients at CEAP stage C5, SDX treatment for 2 months was associated with reduction in MMP-9 serum level ${ }^{[196]}$. Also, treatment of leukemia white blood cells in culture with SDX causes reduction in the proMMP-9 and complexed MMP-9 in a concentration-dependent manner ${ }^{[14]}$. We have recently shown that SDX could improve venous contraction. In IVC segments under control basal tension, SDX caused concentration-dependent $(0.001-1 \mathrm{mg} / \mathrm{mL})$ contraction. In IVC segments under prolonged stretch, high $\mathrm{KCl}$-induced contractile response and phenylephrine-elicited contraction were reduced. In IVC under prolonged stretch and pretreated with SDX, the high KCl-induced contractile response was restored and phenylephrine-induced contraction was improved. MMP-2 and MMP-9 levels and activity were increased in IVC segments under prolonged stretch, and reversed to control levels in IVC segments under prolonged stretch and pretreated with SDX. These observations suggest that SDX enhances contraction in veins under protracted stretch likely through decreases in MMP-2 and MMP-9 activity, and these effects could contribute the potential benefits of SDX in CVI and VVs ${ }^{[14]}$.

Interestingly, SDX shows different effects in arteries $v s$. veins. In contrast with the contractile effect of SDX in rat IVC, our recent experiments showed that phenylephrine caused contraction in rat aortic and 
mesenteric artery segments that was decreased in arterial segments pretreated with $1 \mathrm{mg} / \mathrm{mL}$ SDX. Also, in rat aortic and mesenteric artery rings precontracted with phenylephrine, SDX $(0.001-1 \mathrm{mg} / \mathrm{mL})$ caused dose-dependent arterial relaxation. In phenylephrine precontracted aortic and mesenteric arterial segments, SDX-induced relaxation was reduced by removal of the endothelium or treatment with the NO synthase (NOS) blocker N $\omega$-nitro-L-arginine methyl ester (L-NAME), which suggests a role of NO in SDX-induced arterial relaxation. Interestingly, the arterial relaxation and increases in nitrate/nitrite production induced in response to acetylcholine were also enhanced by SDX. These observations suggest that SDX enhances arterial relaxation through endothelial cell-mediated release of NO, a beneficial effect that could improve vasodilation and reduce vasoconstriction in vascular disease ${ }^{[197]}$. In support, meta-analyses of data from randomized controlled trials have shown that treatment with SDX for at least one month may reduce blood pressure in patients with hypertension ${ }^{[195,198]}$.

\section{Inhibitors of MMPs in CVD}

Current treatment of CVD mainly focuses on the symptoms instead of the causes of VVs. The growing evidence of a role of MMPs in the pathogenesis of VVs has generated interest in the effects of MMP inhibitors, and their potential use to reduce the development and/or recurrence of CVD. Inhibitors of MMPs are either endogenous such as TIMPs and $\alpha 2$-macroglobulin, or synthetic $\mathrm{Zn}^{2+}$-dependent and $\mathrm{Zn}^{2+}$ independent compounds.

TIMPs are naturally occurring inhibitors of MMPs that bind to the MMP molecule in a $1: 1$ stoichiometry ${ }^{[199,200]}$. TIMPs have 4 homologous subtypes, TIMP-1, $-2,-3$ and -4 , which have different efficacies in inhibiting various MMPs. TIMP-1 is not a good inhibitor of MMP-19 and MT1-, MT3-, and MT5-MMP, whereas TIMP-2 and -3 are good inhibitors of MT1- and MT2-MMP ${ }^{[201]}$. TIMP-1 and -2 bind MMP-3, and this binding is a 10 -fold stronger than that for MMP- $10^{[202]}$.

Studies have shown higher TIMP-2 expression and greater accumulation of connective tissue in the tunica media of VVs vs. control veins. The expression of TIMP-2 and -3 is also greater in the hypertrophic than atrophic regions of VVs, and in the thicker proximal regions $v s$. the distal regions of VVs. Increases in the expression of TIMPs are predicted to inhibit the activity of proteases, decrease degradation of ECM proteins, promote accumulation of connective tissue, and thicken the vein wall ${ }^{[203]}$. Studies have also identified TIMP- 1 and -3 in the tunica intima and TIMP- $-1,-2$, and -3 in the tunica media of VVs compared to TIMP-1, -2 , and -3 in the tunica intima and TIMP-1 and -2 in the tunica media of control veins ${ }^{[2]}$.

MMP/TIMP imbalance could be an important factor in the pathogenesis of CVD. Studies have shown slight changes in the levels of MMP-7 and -9, and TIMP-1, -2 and -3, increased levels of MMP-1, -2 and -3 levels, and increases in the elastic network and the deposition of collagen type-I, fibrillin-1 and laminin in the vein wall and the skin of patients with VVs compared with control veins isolated from patients undergoing surgical coronary bypass. These observations suggest that MMP/TIMP imbalance disrupts ECM turnover. Also, the observed changes not only in the vein wall but also in the skin of patients with VVs suggest systemic connective tissue remodeling ${ }^{[2]}$. Studies have also shown a decrease in the ratio of MMP-2 to TIMP-1 in avulsed VVs and increased ECM accumulation in the hypertrophic regions of VVs ${ }^{[204]}$. Patients with VLU also show elevated plasma levels of MMP-2 and -9, TIMP-1 and -2, and increased ratio between MMP-2 and TIMP-2. On the other hand, patients with healed VLU show decreases in MMP-9, TIMP-1 and the ratio between MMP-2 and TIMP-2 below basal levels ${ }^{[205]}$, highlighting the importance of examining MMPs and TIMPs in different VVs regions and at different stages of CVD and CVI. 
Divalent ions such as $\mathrm{Cu}^{2+}, \mathrm{Mg}^{2+}$, and $\mathrm{Mn}^{2+}$ inhibit MMPs by interfering with $\mathrm{Zn}^{2+}$ at the $\mathrm{Zn}^{2+}$ binding site in the MMP catalytic domain ${ }^{[206]}$. The MMP $\mathrm{Zn}^{2+}$ binding property has been utilized to develop several MMP inhibitors ${ }^{[4,207]}$. Inhibitors of MMPs usually have a $\mathrm{Zn}^{2+}$ binding side-chain such as carboxylic acid, hydroxamic acid, or a sulfhydryl group ${ }^{[208]}$. $\mathrm{Zn}^{2+}$ binding globulins (ZBGs) inhibit MMPs by displacing the $\mathrm{Zn}^{2+}$-bound water molecule in the MMP catalytic domain. ZBG also functions as anchors to keep the MMP inhibitor attached to the MMP active site and allow it to diffuse inside the substrate-binding pocket ${ }^{[209]}$. Hydroxamic acid-based MMP inhibitors include phosphinamide, succinyl, and sulfonamide hydroxamates ${ }^{[208,210,211]}$. Succinyl hydroxamates such as batimastat (BB-94), marimastat (BB-2516), and ilomastat (GM6001) have a structure similar to collagen, and function as broad spectrum MMP inhibitors through bidentate chelation of $\mathrm{Zn}^{2+[208,212]}$. Other ZBGs such as aminomethyl benzimidazole-containing ZBGs, nitrogen- and phosphorous-based ZBGs, carboxylic acids, sulfonylhydrazides, thiols, and heterocyclic bidentate chelators have also been developed ${ }^{[209,213,214]}$. Mechanism-based MMP inhibitors and tetracyclines also inhibit MMPs by chelation of $\mathrm{Zn}^{2+}$ from the MMP active site ${ }^{[208]}$. An example of mechanism-based MMP inhibitors is SB-3CT or compound- 40 which coordinates with the MMP $\mathrm{Zn}^{2+}$ and allows the conserved Glu202 in the MMP molecule to initiate a nucleophilic attack and form a covalent bond with the MMP inhibitor ${ }^{[209]}$. The mechanism-based MMP inhibitors have an advantage over other $\mathrm{Zn}^{2+}$ chelating MMP inhibitors, as the strong covalent bond between SB-3CT and the MMP molecule prevents dissociation of the MMP inhibitor, and thereby reduces the concentration of MMP inhibitor required to saturate the MMP active site ${ }^{[215]}$.

Other MMP inhibitors including compound-37 do not have ZBGs, and do not bind to the highly-conserved $\mathrm{Zn}^{2+}$ binding site, but rather interact non-covalently with the $\mathrm{S}^{\prime}, \mathrm{S}_{2}^{\prime}, \mathrm{S}^{\prime}$, and $\mathrm{S}^{\prime}$ ' pockets in the MMP molecule in a manner similar to that of the substrate $\mathrm{P}^{\prime}, \mathrm{P}^{\prime}, \mathrm{P}^{\prime}$, and $\mathrm{P}^{\prime}$ substituents ${ }^{[216]}$. The efficacy and specificity of these MMP inhibitors depend on which of the pockets it blocks in the MMP molecule ${ }^{[208]}$.

MMP-specific siRNA inhibits the transcription of specific MMPs ${ }^{[217]}$. Also, some compounds could have pleiotropic properties including inhibition of MMPs. For instance, statins such as atorvastatin decrease MMP-1, -2, and -9 expression in human retinal pigment epithelial cells ${ }^{[218]}$, and inhibit MMP-1, -2, -3, and -9 release from human saphenous vein SMCs, rabbit macrophages and rabbit aortic SMCs ${ }^{[219]}$. Also, treatment of rat models of heart failure with pravastatin suppresses the increases in activity of MMP-2 and $-9^{[220]}$. Although the design and development of MMP inhibitors has shown great advances, doxycycline remains the only MMP inhibitor approved by the $\mathrm{FDA}^{[221]}$. Patients with VLU who received basic compression therapy with or without VVs surgery in addition to oral doxycycline $20 \mathrm{mg}$ b.i.d. for 3 months showed a higher rate of healed VLU than patients receiving basic therapy alone. Of note, the lower VLU healing rate in patients who received basic therapy alone was also associated with increased MMP-9, NGAL and VEGF levels in the plasma, wound fluid and tissue biopsies. Doxycycline therapy through its antiinflammatory actions and MMP inhibition could also improve ECM function and facilitate VLU healing ${ }^{[222]}$. MMP inhibitors have major limitations as they cause several musculoskeletal side-effects including joint pain, stiffness, inflammation, and tendonitis ${ }^{[223]}$. Improved selectivity of MMP inhibitors and their directed targeting locally to the dilated venous segments could enhance their therapeutic potential and minimize their systemic side-effects in the management of CVD.

\section{CONCLUSION AND PERSPECTIVE}

CVD is a challenging venous disorder in terms of understanding its underlying mechanisms and providing effective management. Demographic, genetic and environmental factors have been suggested as predisposing risk factors for CVD. Changes in MMPs could also promote venous dilation. Changes in venous shear stress and endothelial glycocalyx lead to leukocyte and adhesion molecule activation. 
Increased lower extremity venous hydrostatic pressure, elevated levels of HIFs, ROS and RNS tissue metabolites, and inflammation and leukocyte infiltration of the vein wall lead to increases in cytokines and MMP expression/activity, and result in progressive dilation of the vein wall, valve incompetence and venous reflux. MMPs have been localized in different layers of the vein wall. MMPs promote proteolytic degradation of different protein substrates in ECM including collagen and elastin, leading to weakening of the vein wall architecture and venous dilation. MMPs could promote VSM cell migration, growth and apoptosis, and could modulate $\mathrm{K}^{+}$channels, $\mathrm{Ca}^{2+}$ signaling and VSM contraction. MMPs could also affect the endothelium integrity and endothelium-dependent relaxing factors. Current management of VVs includes compression stockings, venotonic drugs, sclerotherapy or surgical procedures to remove the affected veins. Sulodexide has been used successfully in VLU, and may have venotonic and MMP inhibitory effects, which may benefit patients with CVD. The identification of the MMP role in venous tissue remodeling suggests that they could serve as biomarkers for CVD progression and as promising targets in the management of VVs. However, several MMPs may be altered in CVD. Also, changes in the levels of MMPs may not be uniform in different regions of VVs with atrophic regions showing high levels of MMPs and small amount of ECM while the hypertrophic regions show low MMP levels and excessive ECM. Vein tissue remodeling is also a dynamic process so that an upregulation of one MMP in one region could be paralleled by downregulation of another MMP in a different region. MMP activity could also change during the different stages of CVD. MMP activity is controlled by endogenous inhibitors such as TIMPs. Therefore, different types of MMPs and TIMPs should be measured in the different regions of VVs and during the course of CVD. Currently available MMP inhibitors are not very selective and could cause multiple sideeffects $^{[208]}$. The availability of more selective MMP inhibitors and their targeting locally in the veins in close proximity of VVs could limit their systemic side-effects and improve their effectiveness in treatment of CVD.

\section{DECLARATIONS}

Authors' contributions

Contributed to the review: Raffetto JD, Khalil RA.

\section{Availability of data and materials}

Not applicable.

\section{Financial support and sponsorship}

This work was supported by BRI Fund to Sustain Research Excellence from Brigham Research Institute, and grants from National Heart, Lung, and Blood Institute (HL65998, HL111775, R56HL147889, R01HL147889A1).

\section{Conflicts of interest}

Both authors declared that there are no conflicts of interest.

\section{Ethical approval and consent to participate}

Not applicable.

\section{Consent for publication}

Not applicable.

\section{Copyright}

(c) The Author(s) 2021. 


\section{REFERENCES}

1. MacColl E, Khalil RA. Matrix metalloproteinases as regulators of vein structure and function: implications in chronic venous disease. J Pharmacol Exp Ther 2015;355:410-28. DOI PubMed PMC

2. Sansilvestri-Morel P, Fioretti F, Rupin A, et al. Comparison of extracellular matrix in skin and saphenous veins from patients with varicose veins: does the skin reflect venous matrix changes? Clin Sci (Lond) 2007;112:229-39. DOI PubMed

3. Cui N, Hu M, Khalil RA. Biochemical and biological attributes of matrix metalloproteinases. Prog Mol Biol Transl Sci 2017;147:173. DOI PubMed PMC

4. Kucukguven A, Khalil RA. Matrix metalloproteinases as potential targets in the venous dilation associated with varicose veins. Curr Drug Targets 2013;14:287-324. PubMed PMC

5. Chen Y, Peng W, Raffetto JD, Khalil RA. Matrix metalloproteinases in remodeling of lower extremity veins and chronic venous disease. Prog Mol Biol Transl Sci 2017;147:267-99. DOI PubMed PMC

6. Raffetto JD, Calanni F, Mattana P, Khalil RA. Sulodexide promotes venous contraction in rat inferior vena cava. J Vasc Surg Venous Lymphat Disord 2017;5:145. DOI

7. Raffetto JD, Yu W, Wang X, Calanni F, Mattana P, Khalil RA. Sulodexide improves contraction and decreases matrix metalloproteinase-2 and -9 in veins under prolonged stretch. $J$ Cardiovasc Pharmacol 2020;75:211-21. DOI PubMed PMC

8. Eklof B, Rutherford RB, Bergan JJ, et al. Revision of the CEAP classification for chronic venous disorders: consensus statement. $J$ Vasc Surg 2004;40:1248-52. DOI PubMed

9. Lurie F, Passman M, Meisner M, et al. The 2020 update of the CEAP classification system and reporting standards. J Vasc Surg Venous Lymphat Disord 2020;8:342-52. DOI PubMed

10. Beebe-Dimmer JL, Pfeifer JR, Engle JS, Schottenfeld D. The epidemiology of chronic venous insufficiency and varicose veins. Ann Epidemiol 2005;15:175-84. DOI PubMed

11. Raffetto JD, Khalil RA. Mechanisms of varicose vein formation: valve dysfunction and wall dilation. Phlebology 2008;23:85-98. DOI PubMed

12. Zsoter T, Cronin RF. Venous distensibility in patients with varicose veins. Can Med Assoc J 1966;94:1293-7. PubMed PMC

13. Naoum JJ, Hunter GC, Woodside KJ, Chen C. Current advances in the pathogenesis of varicose veins. J Surg Res 2007;141:311-6. DOI PubMed

14. Mannello F, Medda V, Ligi D, Raffetto JD. Glycosaminoglycan sulodexide inhibition of MMP-9 gelatinase secretion and activity: possible pharmacological role against collagen degradation in vascular chronic diseases. Curr Vasc Pharmacol 2013;11:354-65. DOI PubMed

15. Naik B, Kumar M, Khanna AK, Suman PK. Clinico-histopathological study of varicose vein and role of matrix metalloproteinases-1, matrix metalloproteinases- 9 and tissue inhibitor of matrix metalloproteinase-1 in varicose vein formation. Indian J Pathol Microbiol 2016;59:25-30. DOI PubMed

16. Gandhi RH, Irizarry E, Nackman GB, Halpern VJ, Mulcare RJ, Tilson MD. Analysis of the connective tissue matrix and proteolytic activity of primary varicose veins. J Vasc Surg 1993;18:814-20. PubMed

17. Haviarova Z, Weismann P, Stvrtinova V, Benuska J. The determination of the collagen and elastin amount in the human varicose vein by the computer morphometric method. Gen Physiol Biophys 1999;18 Suppl 1:30-3. PubMed

18. Kockx MM, Knaapen MW, Bortier HE, Cromheeke KM, Boutherin-Falson O, Finet M. Vascular remodeling in varicose veins. Angiology 1998;49:871-7. DOI PubMed

19. Sansilvestri-Morel P, Rupin A, Jullien ND, et al. Decreased production of collagen Type III in cultured smooth muscle cells from varicose vein patients is due to a degradation by MMPs: possible implication of MMP-3. J Vasc Res 2005;42:388-98. DOI PubMed

20. Venturi M, Bonavina L, Annoni F, et al. Biochemical assay of collagen and elastin in the normal and varicose vein wall. J Surg Res 1996;60:245-8. DOI PubMed

21. Corcos L, De Anna D, Dini M, Macchi C, Ferrari PA, Dini S. Proximal long saphenous vein valves in primary venous insufficiency. J Mal Vasc 2000;25:27-36. PubMed

22. Psaila JV, Melhuish J. Viscoelastic properties and collagen content of the long saphenous vein in normal and varicose veins. $\mathrm{Br} J$ Surg 1989;76:37-40. DOI PubMed

23. Ono T, Bergan JJ, Schmid-Schonbein GW, Takase S. Monocyte infiltration into venous valves. J Vasc Surg 1998;27:158-66. DOI PubMed

24. Raffetto JD, Qiao X, Beauregard KG, Khalil RA. Estrogen receptor-mediated enhancement of venous relaxation in female rat: implications in sex-related differences in varicose veins. J Vasc Surg 2010;51:972-81. DOI PubMed PMC

25. Mekky S, Schilling RS, Walford J. Varicose veins in women cotton workers. An epidemiological study in England and Egypt. $\mathrm{Br}$ Med J 1969;2:591-5. DOI PubMed PMC

26. Seidell JC, Bakx KC, Deurenberg P, van den Hoogen HJ, Hautvast JG, Stijnen T. Overweight and chronic illness--a retrospective cohort study, with a follow-up of 6-17 years, in men and women of initially 20-50 years of age. J Chronic Dis 1986;39:585-93. DOI PubMed

27. Kaye SA, Folsom AR, Soler JT, Prineas RJ, Potter JD. Associations of body mass and fat distribution with sex hormone concentrations in postmenopausal women. Int J Epidemiol 1991;20:151-6. DOI PubMed

28. Challis JRG, Matthews SG, Gibb W, Lye SJ. Endocrine and paracrine regulation of birth at term and preterm. Endocr Rev 2000;21:514-50. DOI PubMed

29. Bernstein IM, Ziegler W, Badger GJ. Plasma volume expansion in early pregnancy. Obstet Gynecol 2001;97:669-72. DOI PubMed 
30. Chapman AB, Abraham WT, Zamudio S, et al. Temporal relationships between hormonal and hemodynamic changes in early human pregnancy. Kidney Int 1998;54:2056-63. DOI PubMed

31. Stansby G. Women, pregnancy, and varicose veins. Lancet 2000;355:1117-8. DOI PubMed

32. Jawien A. The influence of environmental factors in chronic venous insufficiency. Angiology 2003;54 Suppl 1:S19-31. DOI PubMed

33. Lacroix P, Aboyans V, Preux PM, Houles MB, Laskar M. Epidemiology of venous insufficiency in an occupational population. Int Angiol 2003;22:172-6. PubMed

34. Abramson JH, Hopp C, Epstein LM. The epidemiology of varicose veins. A survey in western Jerusalem. J Epidemiol Community Health 1981;35:213-7. DOI PubMed PMC

35. Lee S, Lee W, Choe Y, et al. Gene expression profiles in varicose veins using complementary DNA microarray. Dermatol Surg 2005;31:391-5. DOI PubMed

36. Anwar MA, Georgiadis KA, Shalhoub J, Lim CS, Gohel MS, Davies AH. A review of familial, genetic, and congenital aspects of primary varicose vein disease. Circ Cardiovasc Genet 2012;5:460-6. DOI PubMed

37. Reagan B, Folse R. Lower limb venous dynamics in normal persons and children of patients with varicose veins. Surg Gynecol Obstet 1971;132:15-8. PubMed

38. Fukaya E, Flores AM, Lindholm D, et al. Clinical and genetic determinants of varicose veins. Circulation 2018;138:2869-80. DOI PubMed PMC

39. Badauy CM, Gomes SS, Sant'Ana Filho M, Chies JA. Ehlers-Danlos syndrome (EDS) type IV: review of the literature. Clin Oral Investig 2007;11:183-7. DOI PubMed

40. Dalal A, Phadke SR. Hemihyperplasia with Ehlers-Danlos syndrome like skin changes. Clin Dysmorphol 2005;14:207-8. DOI PubMed

41. McKusick VA. The defect in Marfan syndrome. Nature 1991;352:279-81. DOI PubMed

42. Ng MY, Andrew T, Spector TD, Jeffery S. Linkage to the FOXC2 region of chromosome 16 for varicose veins in otherwise healthy, unselected sibling pairs. J Med Genet 2005;42:235-9. DOI PubMed PMC

43. Serra R, Buffone G, de Franciscis A, et al. A genetic study of chronic venous insufficiency. Ann Vasc Surg 2012;26:636-42. DOI PubMed

44. Noel AA, Gloviczki P, Cherry KJ Jr, Rooke TW, Stanson AW, Driscoll DJ. Surgical treatment of venous malformations in KlippelTrenaunay syndrome. J Vasc Surg 2000;32:840-7. DOI PubMed

45. Delis KT, Gloviczki P, Wennberg PW, Rooke TW, Driscoll DJ. Hemodynamic impairment, venous segmental disease, and clinical severity scoring in limbs with Klippel-Trenaunay syndrome. J Vasc Surg 2007;45:561-7. DOI PubMed

46. Saiki S, Sakai K, Saiki M, et al. Varicose veins associated with CADASIL result from a novel mutation in the Notch3 gene. Neurology 2006;67:337-9. DOI PubMed

47. Xu HM, Zhao Y, Zhang XM, Zhu T, Fu WG. Polymorphisms in MMP-9 and TIMP-2 in Chinese patients with varicose veins. $J$ Surg Res 2011;168:e143-8. DOI PubMed

48. Xiao Y, Huang Z, Yin H, Zhang H, Wang S. Desmuslin gene knockdown causes altered expression of phenotype markers and differentiation of saphenous vein smooth muscle cells. J Vasc Surg 2010;52:684-90. DOI PubMed

49. Christopoulos D, Nicolaides AN, Szendro G. Venous reflux: quantification and correlation with the clinical severity of chronic venous disease. Br J Surg 1988;75:352-6. DOI PubMed

50. Zamboni P, Scapoli G, Lanzara V, et al. Serum iron and matrix metalloproteinase-9 variations in limbs affected by chronic venous disease and venous leg ulcers. Dermatol Surg 2005;31:644-9; discussion 649. DOI PubMed

51. Zamboni P, Izzo M, Tognazzo S, et al. The overlapping of local iron overload and HFE mutation in venous leg ulcer pathogenesis. Free Radic Biol Med 2006;40:1869-73. DOI PubMed

52. Zamboni P, De Mattei M, Ongaro A, et al. Factor XIII contrasts the effects of metalloproteinases in human dermal fibroblast cultured cells. Vasc Endovascular Surg 2004;38:431-8. DOI PubMed

53. Zamboni P, Tognazzo S, Izzo M, et al. Hemochromatosis $\mathrm{C} 282 \mathrm{Y}$ gene mutation increases the risk of venous leg ulceration. $J$ Vasc Surg 2005;42:309-14. DOI PubMed

54. Tognazzo S, Gemmati D, Palazzo A, et al. Prognostic role of factor XIII gene variants in nonhealing venous leg ulcers. J Vasc Surg 2006;44:815-9. DOI PubMed

55. Gemmati D, Tognazzo S, Catozzi L, et al. Influence of gene polymorphisms in ulcer healing process after superficial venous surgery. J Vasc Surg 2006;44:554-62. DOI PubMed

56. Dzieciuchowicz L, Espinosa G, Paramo JA. Increased levels of metalloproteinase 10 and hemostatic markers in patients with noncomplicated primary varicose veins. Clin Appl Thromb Hemost 2015;21:684-7. DOI PubMed

57. Gillespie DL, Patel A, Fileta B, et al. Varicose veins possess greater quantities of MMP-1 than normal veins and demonstrate regional variation in MMP-1 and MMP-13. J Surg Res 2002;106:233-8. DOI PubMed

58. Woodside KJ, Hu M, Burke A, et al. Morphologic characteristics of varicose veins: possible role of metalloproteinases. J Vasc Surg 2003;38:162-9. DOI PubMed

59. Thulesius O. The venous wall and valvular function in chronic venous insufficiency. Int Angiol 1996;15:114-8. PubMed

60. Gomez I, Benyahia C, Louedec L, et al. Decreased PGE(2) content reduces MMP-1 activity and consequently increases collagen density in human varicose vein. PLoS One 2014;9:e88021. DOI PubMed PMC

61. Serra R, Gallelli L, Butrico L, et al. From varices to venous ulceration: the story of chronic venous disease described by metalloproteinases. Int Wound J 2017;14:233-40. DOI PubMed 
62. Amato B, Coretti G, Compagna R, et al. Role of matrix metalloproteinases in non-healing venous ulcers. Int Wound J 2015;12:641-5. DOI PubMed

63. Serra R, Grande R, Buffone G, et al. Extracellular matrix assessment of infected chronic venous leg ulcers: role of metalloproteinases and inflammatory cytokines. Int Wound J 2016;13:53-8. DOI PubMed

64. Asanuma K, Magid R, Johnson C, Nerem RM, Galis ZS. Uniaxial strain upregulates matrix-degrading enzymes produced by human vascular smooth muscle cells. Am J Physiol Heart Circ Physiol 2003;284:H1778-84. DOI PubMed

65. Raffetto JD, Qiao X, Koledova VV, Khalil RA. Prolonged increases in vein wall tension increase matrix metalloproteinases and decrease constriction in rat vena cava: Potential implications in varicose veins. J Vasc Surg 2008;48:447-56. DOI PubMed PMC

66. Lim CS, Qiao X, Reslan OM, et al. Prolonged mechanical stretch is associated with upregulation of hypoxia-inducible factors and reduced contraction in rat inferior vena cava. J Vasc Surg 2011;53:764-73. DOI PubMed PMC

67. Milkiewicz M, Doyle JL, Fudalewski T, Ispanovic E, Aghasi M, Haas TL. HIF-1alpha and HIF-2alpha play a central role in stretchinduced but not shear-stress-induced angiogenesis in rat skeletal muscle. J Physiol 2007;583:753-66. DOI PubMed PMC

68. Kim CH, Cho YS, Chun YS, Park JW, Kim MS. Early expression of myocardial HIF-1alpha in response to mechanical stresses: regulation by stretch-activated channels and the phosphatidylinositol 3-kinase signaling pathway. Circ Res 2002;90:E25-33. DOI PubMed

69. Thodeti CK, Matthews B, Ravi A, et al. TRPV4 channels mediate cyclic strain-induced endothelial cell reorientation through integrin-to-integrin signaling. Circ Res 2009;104:1123-30. DOI PubMed PMC

70. Lim CS, Kiriakidis S, Paleolog EM, Davies AH. Increased activation of the hypoxia-inducible factor pathway in varicose veins. $J$ Vasc Surg 2012;55:1427-39. DOI PubMed

71. Misra S, Fu AA, Rajan DK, et al. Expression of hypoxia inducible factor-1 alpha, macrophage migration inhibition factor, matrix metalloproteinase-2 and -9, and their inhibitors in hemodialysis grafts and arteriovenous fistulas. $J$ Vasc Interv Radiol 2008;19:252-9. DOI PubMed

72. Anwar MA, Shalhoub J, Vorkas PA, et al. In-vitro identification of distinctive metabolic signatures of intact varicose vein tissue via magic angle spinning nuclear magnetic resonance spectroscopy. Eur J Vasc Endovasc Surg 2012;44:442-50. DOI PubMed

73. Anwar MA, Vorkas PA, Li J, et al. Prolonged mechanical circumferential stretch induces metabolic changes in rat inferior vena cava. Eur J Vasc Endovasc Surg 2016;52:544-52. DOI PubMed PMC

74. Schmid-Schonbein GW, Takase S, Bergan JJ. New advances in the understanding of the pathophysiology of chronic venous insufficiency. Angiology 2001;52 Suppl 1:S27-34. DOI PubMed

75. Mannello F, Raffetto JD. Matrix metalloproteinase activity and glycosaminoglycans in chronic venous disease: the linkage among cell biology, pathology and translational research. Am J Transl Res 2011;3:149-58. PubMed PMC

76. Raffetto JD, Ligi D, Maniscalco R, Khalil RA, Mannello F. Why venous leg ulcers have difficulty healing: overview on pathophysiology, clinical consequences, and treatment. J Clin Med 2020;10:29. DOI PubMed PMC

77. Zeng Y. Endothelial glycocalyx as a critical signalling platform integrating the extracellular haemodynamic forces and chemical signalling. J Cell Mol Med 2017;21:1457-62. DOI PubMed PMC

78. Liu JX, Yan ZP, Zhang YY, Wu J, Liu XH, Zeng Y. Hemodynamic shear stress regulates the transcriptional expression of heparan sulfate proteoglycans in human umbilical vein endothelial cell. Cell Mol Biol (Noisy-le-grand) 2016;62:28-34. PubMed

79. Moazzam F, DeLano FA, Zweifach BW, Schmid-Schonbein GW. The leukocyte response to fluid stress. Proc Natl Acad Sci U S A 1997;94:5338-43. DOI PubMed PMC

80. Alsaigh T, Pocock ES, Bergan JJ, Schmid-Schonbein GW. Acute venous occlusion enhances matrix metalloprotease activity: Implications on endothelial dysfunction. Microvasc Res 2011;81:108-16. DOI PubMed PMC

81. Takase S, Pascarella L, Bergan JJ, Schmid-Schonbein GW. Hypertension-induced venous valve remodeling. J Vasc Surg 2004;39:1329-34. DOI PubMed

82. Saito S, Trovato MJ, You R, et al. Role of matrix metalloproteinases 1, 2, and 9 and tissue inhibitor of matrix metalloproteinase-1 in chronic venous insufficiency. J Vasc Surg 2001;34:930-8. DOI PubMed

83. Sayer GL, Smith PD. Immunocytochemical characterisation of the inflammatory cell infiltrate of varicose veins. Eur J Vasc Endovasc Surg 2004;28:479-83. DOI PubMed

84. Aunapuu M, Arend A. Histopathological changes and expression of adhesion molecules and laminin in varicose veins. Vasa 2005;34:170-5. DOI PubMed

85. Jacob MP, Cazaubon M, Scemama A, et al. Plasma matrix metalloproteinase-9 as a marker of blood stasis in varicose veins. Circulation 2002;106:535-8. DOI PubMed

86. Sato H, Kita M, Seiki M. v-Src activates the expression of 92-kDa type IV collagenase gene through the AP-1 site and the GT box homologous to retinoblastoma control elements. A mechanism regulating gene expression independent of that by inflammatory cytokines. J Biol Chem 1993;268:23460-8. PubMed

87. Reddy VS, Prabhu SD, Mummidi S, et al. Interleukin-18 induces EMMPRIN expression in primary cardiomyocytes via JNK/Sp1 signaling and MMP-9 in part via EMMPRIN and through AP-1 and NF-kappaB activation. Am J Physiol Heart Circ Physiol 2010;299:H1242-54. DOI PubMed PMC

88. Arbiser JL, Petros J, Klafter R, et al. Reactive oxygen generated by Nox1 triggers the angiogenic switch. Proc Natl Acad Sci U S A 2002;99:715-20. DOI PubMed PMC

89. Zubkova ES, Men'shikov MY, Plekhanova OS, Beloglazova IB, Ratner EI, Parfenova EV. Urokinase stimulates production of matrix metalloproteinase-9 in fibroblasts with involvement of reactive oxygen species. Bull Exp Biol Med 2014;157:18-21. DOI PubMed

90. Fu X, Kao JL, Bergt C, et al. Oxidative cross-linking of tryptophan to glycine restrains matrix metalloproteinase activity: specific 
structural motifs control protein oxidation. J Biol Chem 2004;279:6209-12. DOI PubMed

91. Bodnar E, Bakondi E, Kovacs K, et al. Redox Profiling Reveals Clear Differences between molecular patterns of wound fluids from acute and chronic wounds. Oxid Med Cell Longev 2018;2018:5286785. DOI PubMed PMC

92. Foda HD, Rollo EE, Drews M, et al. Ventilator-induced lung injury upregulates and activates gelatinases and EMMPRIN: attenuation by the synthetic matrix metalloproteinase inhibitor, Prinomastat (AG3340). Am J Respir Cell Mol Biol 2001;25:717-24. DOI PubMed

93. Norgauer J, Hildenbrand T, Idzko M, et al. Elevated expression of extracellular matrix metalloproteinase inducer (CD147) and membrane-type matrix metalloproteinases in venous leg ulcers. Br J Dermatol 2002;147:1180-6. DOI PubMed

94. Majed BH, Khalil RA. Molecular mechanisms regulating the vascular prostacyclin pathways and their adaptation during pregnancy and in the newborn. Pharmacol Rev 2012;64:540-82. DOI PubMed PMC

95. Lee J, Banu SK, Subbarao T, Starzinski-Powitz A, Arosh JA. Selective inhibition of prostaglandin E2 receptors EP2 and EP4 inhibits invasion of human immortalized endometriotic epithelial and stromal cells through suppression of metalloproteinases. Mol Cell Endocrinol 2011;332:306-13. DOI PubMed

96. Takai S, Jin D, Chen H, et al. Chymase inhibition improves vascular dysfunction and survival in stroke-prone spontaneously hypertensive rats. J Hypertens 2014;32:1637-49. DOI PubMed

97. Yin Z, Sada AA, Reslan OM, Narula N, Khalil RA. Increased MMPs expression and decreased contraction in the rat myometrium during pregnancy and in response to prolonged stretch and sex hormones. Am J Physiol Endocrinol Metab 2012;303:E55-70. DOI PubMed PMC

98. Dang Y, Li W, Tran V, Khalil RA. EMMPRIN-mediated induction of uterine and vascular matrix metalloproteinases during pregnancy and in response to estrogen and progesterone. Biochem Pharmacol 2013;86:734-47. DOI PubMed PMC

99. Serra R, Gallelli L, Conti A, et al. The effects of sulodexide on both clinical and molecular parameters in patients with mixed arterial and venous ulcers of lower limbs. Drug Des Devel Ther 2014;8:519-27. DOI PubMed PMC

100. Badier-Commander C, Verbeuren T, Lebard C, Michel JB, Jacob MP. Increased TIMP/MMP ratio in varicose veins: a possible explanation for extracellular matrix accumulation. J Pathol 2000;192:105-12. DOI PubMed

101. Kirsch D, Dienes HP, Kuchle R, et al. Changes in the extracellular matrix of the vein wall--the cause of primary varicosis? Vasa 2000;29:173-7. DOI PubMed

102. Sansilvestri-Morel P, Rupin A, Badier-Commander C, et al. Imbalance in the synthesis of collagen type I and collagen type III in smooth muscle cells derived from human varicose veins. J Vasc Res 2001;38:560-8. DOI PubMed

103. Shi ZD, Ji XY, Berardi DE, Qazi H, Tarbell JM. Interstitial flow induces MMP-1 expression and vascular SMC migration in collagen I gels via an ERK1/2-dependent and c-Jun-mediated mechanism. Am J Physiol Heart Circ Physiol 2010;298:H127-35. DOI PubMed PMC

104. Jin UH, Suh SJ, Chang HW, et al. Tanshinone IIA from Salvia miltiorrhiza BUNGE inhibits human aortic smooth muscle cell migration and MMP-9 activity through AKT signaling pathway. J Cell Biochem 2008;104:15-26. DOI PubMed

105. Haque NS, Fallon JT, Pan JJ, Taubman MB, Harpel PC. Chemokine receptor-8 (CCR8) mediates human vascular smooth muscle cell chemotaxis and metalloproteinase-2 secretion. Blood 2004;103:1296-304. DOI PubMed

106. Cheng XW, Kuzuya M, Sasaki T, et al. Increased expression of elastolytic cysteine proteases, cathepsins S and K, in the neointima of balloon-injured rat carotid arteries. Am J Pathol 2004;164:243-51. DOI PubMed PMC

107. Johnson C, Galis ZS. Matrix metalloproteinase-2 and -9 differentially regulate smooth muscle cell migration and cell-mediated collagen organization. Arterioscler Thromb Vasc Biol 2004;24:54-60. DOI PubMed

108. Cho A, Reidy MA. Matrix metalloproteinase-9 is necessary for the regulation of smooth muscle cell replication and migration after arterial injury. Circ Res 2002;91:845-51. DOI PubMed

109. Galis ZS, Johnson C, Godin D, et al. Targeted disruption of the matrix metalloproteinase-9 gene impairs smooth muscle cell migration and geometrical arterial remodeling. Circ Res 2002;91:852-9. DOI PubMed

110. Aguilera CM, George SJ, Johnson JL, Newby AC. Relationship between type IV collagen degradation, metalloproteinase activity and smooth muscle cell migration and proliferation in cultured human saphenous vein. Cardiovasc Res 2003;58:679-88. DOI PubMed

111. Carragher NO, Frame MC. Focal adhesion and actin dynamics: a place where kinases and proteases meet to promote invasion. Trends Cell Biol 2004;14:241-9. DOI PubMed

112. Nelson WJ, Nusse R. Convergence of Wnt, beta-catenin, and cadherin pathways. Science 2004;303:1483-7. DOI PubMed PMC

113. Savani RC, Wang C, Yang B, et al. Migration of bovine aortic smooth muscle cells after wounding injury. The role of hyaluronan and RHAMM. J Clin Invest 1995;95:1158-68. DOI PubMed PMC

114. Uglow EB, Slater S, Sala-Newby GB, et al. Dismantling of cadherin-mediated cell-cell contacts modulates smooth muscle cell proliferation. Circ Res 2003;92:1314-21. DOI PubMed

115. Boire A, Covic L, Agarwal A, Jacques S, Sherifi S, Kuliopulos A. PAR1 is a matrix metalloprotease-1 receptor that promotes invasion and tumorigenesis of breast cancer cells. Cell 2005;120:303-13. DOI PubMed

116. Somers P, Knaapen M. The histopathology of varicose vein disease. Angiology 2006;57:546-55. DOI PubMed

117. Wali MA, Eid RA. Smooth muscle changes in varicose veins: an ultrastructural study. J Smooth Muscle Res 2001;37:123-35. DOI PubMed

118. Wali MA, Eid RA. Intimal changes in varicose veins: an ultrastructural study. J Smooth Muscle Res 2002;38:63-74. DOI PubMed

119. Elsharawy MA, Naim MM, Abdelmaguid EM, Al-Mulhim AA. Role of saphenous vein wall in the pathogenesis of primary varicose veins. Interact Cardiovasc Thorac Surg 2007;6:219-24. DOI PubMed

120. Xiao Y, Huang Z, Yin H, Lin Y, Wang S. In vitro differences between smooth muscle cells derived from varicose veins and normal 
veins. J Vasc Surg 2009;50:1149-54. DOI PubMed

121. Morla AO, Mogford JE. Control of smooth muscle cell proliferation and phenotype by integrin signaling through focal adhesion kinase. Biochem Biophys Res Commun 2000;272:298-302. DOI PubMed

122. Karsdal MA, Larsen L, Engsig MT, et al. Matrix metalloproteinase-dependent activation of latent transforming growth factor-beta controls the conversion of osteoblasts into osteocytes by blocking osteoblast apoptosis. J Biol Chem 2002;277:44061-7. DOI PubMed

123. Mao D, Zhang Y, Lu H, Zhang H. Molecular basis underlying inhibition of metastasis of gastric cancer by anti-VEGFa treatment. Tumour Biol 2014;35:8217-23. DOI PubMed

124. Zhang H, Chalothorn D, Jackson LF, Lee DC, Faber JE. Transactivation of epidermal growth factor receptor mediates catecholamineinduced growth of vascular smooth muscle. Circ Res 2004;95:989-97. DOI PubMed

125. Frisch SM, Screaton RA. Anoikis mechanisms. Curr Opin Cell Biol 2001;13:555-62. DOI PubMed

126. Almeida EA, Ilic D, Han Q, et al. Matrix survival signaling: from fibronectin via focal adhesion kinase to c-Jun NH(2)-terminal kinase. J Cell Biol 2000;149:741-54. DOI PubMed PMC

127. Ilic D, Almeida EA, Schlaepfer DD, Dazin P, Aizawa S, Damsky CH. Extracellular matrix survival signals transduced by focal adhesion kinase suppress p53-mediated apoptosis. J Cell Biol 1998;143:547-60. DOI PubMed PMC

128. Levkau B, Kenagy RD, Karsan A, et al. Activation of metalloproteinases and their association with integrins: an auxiliary apoptotic pathway in human endothelial cells. Cell Death Differ 2002;9:1360-7. DOI PubMed

129. Visse R, Nagase H. Matrix metalloproteinases and tissue inhibitors of metalloproteinases: structure, function, and biochemistry. Circ Res 2003;92:827-39. DOI PubMed

130. Somerville RP, Oblander SA, Apte SS. Matrix metalloproteinases: old dogs with new tricks. Genome Biol 2003;4:216. DOI PubMed PMC

131. Mannello F, Luchetti F, Falcieri E, Papa S. Multiple roles of matrix metalloproteinases during apoptosis. Apoptosis 2005;10:19-24. DOI PubMed

132. Bond M, Murphy G, Bennett MR, et al. Localization of the death domain of tissue inhibitor of metalloproteinase- 3 to the $\mathrm{N}$ terminus. Metalloproteinase inhibition is associated with proapoptotic activity. J Biol Chem 2000;275:41358-63. DOI PubMed

133. Kwan JA, Schulze CJ, Wang W, et al. Matrix metalloproteinase-2 (MMP-2) is present in the nucleus of cardiac myocytes and is capable of cleaving poly (ADP-ribose) polymerase (PARP) in vitro. FASEB J 2004;18:690-2. DOI PubMed

134. Nagareddy PR, Chow FL, Hao L, et al. Maintenance of adrenergic vascular tone by MMP transactivation of the EGFR requires PI3K and mitochondrial ATP synthesis. Cardiovasc Res 2009;84:368-77. DOI PubMed

135. Chew DK, Conte MS, Khalil RA. Matrix metalloproteinase-specific inhibition of Ca2+ entry mechanisms of vascular contraction. $J$ Vasc Surg 2004;40:1001-10. DOI PubMed

136. Raffetto JD, Barros YV, Wells AK, Khalil RA. MMP-2 induced vein relaxation via inhibition of [Ca2+]e-dependent mechanisms of venous smooth muscle contraction. Role of RGD peptides. J Surg Res 2010;159:755-64. DOI PubMed PMC

137. Waitkus-Edwards KR, Martinez-Lemus LA, Wu X, et al. Alpha(4)beta(1) Integrin activation of L-type calcium channels in vascular smooth muscle causes arteriole vasoconstriction. Circ Res 2002;90:473-80. DOI PubMed

138. Macfarlane SR, Seatter MJ, Kanke T, Hunter GD, Plevin R. Proteinase-activated receptors. Pharmacol Rev 2001;53:245-82. PubMed

139. Hamilton JR, Nguyen PB, Cocks TM. Atypical protease-activated receptor mediates endothelium-dependent relaxation of human coronary arteries. Circ Res 1998;82:1306-11. DOI PubMed

140. Raffetto JD, Ross RL, Khalil RA. Matrix metalloproteinase 2-induced venous dilation via hyperpolarization and activation of K+ channels: relevance to varicose vein formation. J Vasc Surg 2007;45:373-80. DOI PubMed PMC

141. Goerge T, Barg A, Schnaeker EM, et al. Tumor-derived matrix metalloproteinase-1 targets endothelial proteinase-activated receptor 1 promoting endothelial cell activation. Cancer Res 2006;66:7766-74. DOI PubMed

142. Tarin C, Gomez M, Calvo E, Lopez JA, Zaragoza C. Endothelial nitric oxide deficiency reduces MMP-13-mediated cleavage of ICAM-1 in vascular endothelium: a role in atherosclerosis. Arterioscler Thromb Vasc Biol 2009;29:27-32. DOI PubMed

143. Louboutin JP, Agrawal L, Reyes BA, Van Bockstaele EJ, Strayer DS. HIV-1 gp120-induced injury to the blood-brain barrier: role of metalloproteinases 2 and 9 and relationship to oxidative stress. J Neuropathol Exp Neurol 2010;69:801-16. DOI PubMed PMC

144. Thanabalasundaram G, Pieper C, Lischper M, Galla HJ. Regulation of the blood-brain barrier integrity by pericytes via matrix metalloproteinases mediated activation of vascular endothelial growth factor in vitro. Brain Res 2010;1347:1-10. DOI PubMed

145. Lischper M, Beuck S, Thanabalasundaram G, Pieper C, Galla HJ. Metalloproteinase mediated occludin cleavage in the cerebral microcapillary endothelium under pathological conditions. Brain Res 2010;1326:114-27. DOI PubMed

146. Feletou M, Vanhoutte PM. Endothelium-derived hyperpolarizing factor: where are we now? Arterioscler Thromb Vasc Biol 2006;26:1215-25. DOI PubMed

147. McNamara CA, Sarembock IJ, Gimple LW, Fenton JW 2nd, Coughlin SR, Owens GK. Thrombin stimulates proliferation of cultured rat aortic smooth muscle cells by a proteolytically activated receptor. J Clin Invest 1993;91:94-8. DOI PubMed PMC

148. Coughlin SR. Thrombin signalling and protease-activated receptors. Nature 2000;407:258-64. DOI PubMed

149. Garcia JG, Patterson C, Bahler C, Aschner J, Hart CM, English D. Thrombin receptor activating peptides induce Ca2+ mobilization, barrier dysfunction, prostaglandin synthesis, and platelet-derived growth factor mRNA expression in cultured endothelium. $J$ Cell Physiol 1993;156:541-9. DOI PubMed

150. Lee HY, You HJ, Won JY, et al. Forkhead factor, FOXO3a, induces apoptosis of endothelial cells through activation of matrix metalloproteinases. Arterioscler Thromb Vasc Biol 2008;28:302-8. DOI PubMed 
151. Lattimer CR, Kalodiki E, Kafeza M, Azzam M, Geroulakos G. Quantifying the degree graduated elastic compression stockings enhance venous emptying. Eur J Vasc Endovasc Surg 2014;47:75-80. DOI PubMed

152. Horner J, Fernandes J, Fernandes E, Nicolaides AN. Value of graduated compression stockings in deep venous insufficiency. $\mathrm{Br}$ Med $J$ 1980;280:820-1. DOI PubMed PMC

153. Lattimer CR, Azzam M, Kalodiki E, Makris GC, Geroulakos G. Compression stockings significantly improve hemodynamic performance in post-thrombotic syndrome irrespective of class or length. J Vasc Surg 2013;58:158-65. DOI PubMed

154. Krajnovic P. Effect of a benzopyrone preparation in venous diseases during pregnancy. Med Monatsschr 1977;31:86-8. PubMed

155. Bergan JJ. Chronic venous insufficiency and the therapeutic effects of Daflon $500 \mathrm{mg}$. Angiology 2005;56 Suppl 1:S21-4. DOI PubMed

156. Frick RW. Three treatments for chronic venous insufficiency: escin, hydroxyethylrutoside, and Daflon. Angiology 2000;51:197-205. DOI PubMed

157. Sirtori CR. Aescin: pharmacology, pharmacokinetics and therapeutic profile. Pharmacol Res 2001;44:183-93. DOI PubMed

158. Devehat C, Khodabandehlou T, Vimeux M, Kempf C. Evaluation of haemorheological and microcirculatory disturbances in chronic venous insufficiency: activity of Daflon $500 \mathrm{mg}$. Int J Microcirc Clin Exp 1997;17 Suppl 1:27-33. DOI PubMed

159. Smith PD. From skin disorders to venous leg ulcers: pathophysiology and efficacy of Daflon $500 \mathrm{mg}$ in ulcer healing. Angiology 2003;54 Suppl 1:S45-50. DOI PubMed

160. Siebert U, Brach M, Sroczynski G, Berla K. Efficacy, routine effectiveness, and safety of horsechestnut seed extract in the treatment of chronic venous insufficiency. A meta-analysis of randomized controlled trials and large observational studies. Int Angiol 2002;21:305-15. PubMed

161. Pittler MH, Ernst E. Horse chestnut seed extract for chronic venous insufficiency. Cochrane Database Syst Rev 2006;11:CD003230. DOI PubMed

162. Berti F, Omini C, Longiave D. The mode of action of aescin and the release of prostaglandins. Prostaglandins 1977;14:241-9. DOI PubMed

163. Carrasco OF, Vidrio H. Endothelium protectant and contractile effects of the antivaricose principle escin in rat aorta. Vascul Pharmacol 2007;47:68-73. DOI PubMed

164. Savineau JP, Marthan R. Diosmin-induced increase in sensitivity to Ca2+ of the smooth muscle contractile apparatus in the rat isolated femoral vein. Br J Pharmacol 1994;111:978-80. DOI PubMed PMC

165. Heijs BG, Blange T, Jongsma HJ, De Beer EL. The length dependency of calcium activated contractions in the femoral artery smooth muscle studied with different methods of skinning. J Muscle Res Cell Motil 2000;21:59-66. DOI PubMed

166. Kobayashi S, Kitazawa T, Somlyo AV, Somlyo AP. Cytosolic heparin inhibits muscarinic and alpha-adrenergic Ca2+ release in smooth muscle. Physiological role of inositol 1,4,5-trisphosphate in pharmacomechanical coupling. J Biol Chem 1989;264:179978004. PubMed

167. Boudet C, Peyrin L. Comparative effect of tropolone and diosmin on venous COMT and sympathetic activity in rat. Arch Int Pharmacodyn Ther 1986;283:312-20. PubMed

168. Araujo D, Viana F, Osswald W. Diosmin therapy alters the in vitro metabolism of noradrenaline by the varicose human saphenous vein. Pharmacol Res 1991;24:253-6. DOI PubMed

169. Raffetto JD, Khalil RA. Ca(2+)-dependent contraction by the saponoside escin in rat vena cava: implications in venotonic treatment of varicose veins. J Vasc Surg 2011;54:489-96. DOI PubMed PMC

170. Cesarone MR, Belcaro G, Pellegrini L, et al. Venoruton vs Daflon: evaluation of effects on quality of life in chronic venous insufficiency. Angiology 2006;57:131-8. DOI PubMed

171. Raffetto JD, Eberhardt RT, Dean SM, Ligi D, Mannello F. Pharmacologic treatment to improve venous leg ulcer healing. J Vasc Surg Venous Lymphat Disord 2016;4:371-4. DOI PubMed

172. Mann MW. Sclerotherapy: it is back and better. Clin Plast Surg 2011;38:475-87, vii. DOI PubMed

173. King JT, O'Byrne M, Vasquez M, Wright D. Treatment of truncal incompetence and varicose veins with a single administration of a new polidocanol endovenous microfoam preparation improves symptoms and appearance. Eur J Vasc Endovasc Surg 2015;50:78493. DOI PubMed

174. Proebstle TM, Lehr HA, Kargl A, et al. Endovenous treatment of the greater saphenous vein with a 940-nm diode laser: thrombotic occlusion after endoluminal thermal damage by laser-generated steam bubbles. J Vasc Surg 2002;35:729-36. DOI PubMed

175. Merchant RF, Pichot O, Myers KA. Four-year follow-up on endovascular radiofrequency obliteration of great saphenous reflux. Dermatol Surg 2005;31:129-34. DOI PubMed

176. Min RJ, Khilnani N, Zimmet SE. Endovenous laser treatment of saphenous vein reflux: long-term results. J Vasc Interv Radiol 2003;14:991-6. DOI PubMed

177. Sarin S, Scurr JH, Coleridge Smith PD. Stripping of the long saphenous vein in the treatment of primary varicose veins. Br J Surg 1994;81:1455-8. DOI PubMed

178. Aremu MA, Mahendran B, Butcher W, et al. Prospective randomized controlled trial: conventional versus powered phlebectomy. $J$ Vasc Surg 2004;39:88-94. DOI PubMed

179. Bootun R, Lane TR, Davies AH. The advent of non-thermal, non-tumescent techniques for treatment of varicose veins. Phlebology 2016;31:5-14. DOI PubMed

180. Tekin AI, Tuncer ON, Memetoglu ME, et al. Nonthermal, nontumescent endovenous treatment of varicose veins. Ann Vasc Surg 2016;36:231-5. DOI PubMed

181. Andreozzi GM, Bignamini AA, Davi G, et al. Sulodexide for the prevention of recurrent venous thromboembolism: the sulodexide in 
secondary prevention of recurrent deep vein thrombosis (SURVET) study: a multicenter, randomized, double-blind, placebocontrolled trial. Circulation 2015;132:1891-7. DOI PubMed PMC

182. Coccheri S, Mannello F. Development and use of sulodexide in vascular diseases: implications for treatment. Drug Des Devel Ther 2014;8:49-65. DOI PubMed PMC

183. Lauver DA, Lucchesi BR. Sulodexide: a renewed interest in this glycosaminoglycan. Cardiovasc Drug Rev 2006;24:214-26. DOI PubMed

184. Coccheri S, Scondotto G, Agnelli G, Aloisi D, Palazzini E, Zamboni V. Randomised, double blind, multicentre, placebo controlled study of sulodexide in the treatment of venous leg ulcers. Thromb Haemost 2002;87:947-52. PubMed

185. Scondotto G, Aloisi D, Ferrari P, Martini L. Treatment of venous leg ulcers with sulodexide. Angiology 1999;50:883-9. DOI PubMed

186. Coccheri S. Biological and clinical effects of sulodexide in arterial disorders and diseases. Int Angiol 2014;33:263-74. PubMed

187. Andreozzi GM. Role of sulodexide in the treatment of CVD. Int Angiol 2014;33:255-62. PubMed

188. Liu YN, Zhou J, Li T, et al. Sulodexide protects renal tubular epithelial cells from oxidative stress-induced injury via upregulating klotho expression at an early stage of diabetic kidney disease. J Diabetes Res 2017;2017:4989847. DOI PubMed PMC

189. Pletinck A, Van Landschoot M, Steppan S, et al. Oral supplementation with sulodexide inhibits neo-angiogenesis in a rat model of peritoneal perfusion. Nephrol Dial Transplant 2012;27:548-56. DOI PubMed

190. Ligi D, Benitez S, Croce L, et al. Electronegative LDL induces MMP-9 and TIMP-1 release in monocytes through CD14 activation: Inhibitory effect of glycosaminoglycan sulodexide. Biochim Biophys Acta Mol Basis Dis 2018;1864:3559-67. DOI PubMed

191. Ciszewicz M, Polubinska A, Antoniewicz A, Suminska-Jasinska K, Breborowicz A. Sulodexide suppresses inflammation in human endothelial cells and prevents glucose cytotoxicity. Transl Res 2009;153:118-23. DOI PubMed

192. Harenberg J. Review of pharmacodynamics, pharmacokinetics, and therapeutic properties of sulodexide. Med Res Rev 1998;18:1-20. DOI PubMed

193. Suminska-Jasinska K, Polubinska A, Ciszewicz M, Mikstacki A, Antoniewicz A, Breborowicz A. Sulodexide reduces senescencerelated changes in human endothelial cells. Med Sci Monit 2011;17:CR222-6. DOI PubMed PMC

194. Polubinska A, Staniszewski R, Baum E, Suminska-Jasinska K, Breborowicz A. Sulodexide modifies intravascular homeostasis what affects function of the endothelium. Adv Med Sci 2013;58:304-10. DOI PubMed

195. Engberink RH, Heerspink HJ, de Zeeuw D, Vogt L. Blood pressure-lowering effects of sulodexide depend on albuminuria severity: post hoc analysis of the sulodexide microalbuminuria and macroalbuminuria studies. Br J Clin Pharmacol 2016;82:1351-7. DOI PubMed PMC

196. Urbanek T, Zbigniew K, Begier-Krasinska B, Baum E, Breborowicz A. Sulodexide suppresses inflammation in patients with chronic venous insufficiency. Int Angiol 2015;34:589-96. PubMed

197. Raffetto JD, Calanni F, Mattana P, Khalil RA. Sulodexide promotes arterial relaxation via endothelium-dependent nitric oxidemediated pathway. Biochem Pharmacol 2019;166:347-56. DOI PubMed PMC

198. Engberink RH, Rorije NM, Lambers Heerspink HJ, De Zeeuw D, van den Born BJ, Vogt L. The blood pressure lowering potential of sulodexide--a systematic review and meta-analysis. Br J Clin Pharmacol 2015;80:1245-53. DOI PubMed PMC

199. Bode W, Fernandez-Catalan C, Grams F, et al. Insights into MMP-TIMP interactions. Ann N Y Acad Sci 1999;878:73-91. DOI PubMed

200. Nagase H, Visse R, Murphy G. Structure and function of matrix metalloproteinases and TIMPs. Cardiovasc Res 2006;69:562-73. DOI PubMed

201. Baker AH, Edwards DR, Murphy G. Metalloproteinase inhibitors: biological actions and therapeutic opportunities. J Cell Sci 2002;115:3719-27. DOI PubMed

202. Batra J, Robinson J, Soares AS, Fields AP, Radisky DC, Radisky ES. Matrix metalloproteinase-10 (MMP-10) interaction with tissue inhibitors of metalloproteinases TIMP-1 and TIMP-2: binding studies and crystal structure. J Biol Chem 2012;287:15935-46. DOI PubMed PMC

203. Aravind B, Saunders B, Navin T, et al. Inhibitory effect of TIMP influences the morphology of varicose veins. Eur J Vasc Endovasc Surg 2010;40:754-65. DOI PubMed

204. Badier-Commander C, Couvelard A, Henin D, Verbeuren T, Michel JB, Jacob MP. Smooth muscle cell modulation and cytokine overproduction in varicose veins. An in situ study. J Pathol 2001;193:398-407. DOI PubMed

205. Caimi G, Ferrara F, Montana M, et al. Behaviour of the plasma concentration of gelatinases and their tissue inhibitors in subjects with venous leg ulcers. Clin Hemorheol Microcirc 2015;60:309-16. DOI PubMed

206. Li PC, Pan CH, Sheu MJ, Wu CC, Ma WF, Wu CH. Deep sea water prevents balloon angioplasty-induced hyperplasia through MMP-2: an in vitro and in vivo study. PLoS One 2014;9:e96927. DOI PubMed PMC

207. Benjamin MM, Khalil RA. Matrix metalloproteinase inhibitors as investigative tools in the pathogenesis and management of vascular disease. Exp Suppl 2012;103:209-79. DOI PubMed PMC

208. Hu J, Van den Steen PE, Sang QX, Opdenakker G. Matrix metalloproteinase inhibitors as therapy for inflammatory and vascular diseases. Nat Rev Drug Discov 2007;6:480-98. DOI PubMed

209. Jacobsen JA, Major Jourden JL, Miller MT, Cohen SM. To bind zinc or not to bind zinc: an examination of innovative approaches to improved metalloproteinase inhibition. Biochim Biophys Acta 2010;1803:72-94. DOI PubMed

210. Scozzafava A, Supuran CT. Carbonic anhydrase and matrix metalloproteinase inhibitors: sulfonylated amino acid hydroxamates with MMP inhibitory properties act as efficient inhibitors of CA isozymes I, II, and IV, and N-hydroxysulfonamides inhibit both these zinc enzymes. J Med Chem 2000;43:3677-87. DOI PubMed 
211. Pochetti G, Gavuzzo E, Campestre C, et al. Structural insight into the stereoselective inhibition of MMP-8 by enantiomeric sulfonamide phosphonates. J Med Chem 2006;49:923-31. DOI PubMed

212. Wojtowicz-Praga SM, Dickson RB, Hawkins MJ. Matrix metalloproteinase inhibitors. Invest New Drugs 1997;15:61-75. DOI PubMed

213. Skiles JW, Gonnella NC, Jeng AY. The design, structure, and therapeutic application of matrix metalloproteinase inhibitors. Curr Med Chem 2001;8:425-74. DOI PubMed

214. Puerta DT, Lewis JA, Cohen SM. New beginnings for matrix metalloproteinase inhibitors: identification of high-affinity zinc-binding groups. J Am Chem Soc 2004;126:8388-9. DOI PubMed

215. Bernardo MM, Brown S, Li ZH, Fridman R, Mobashery S. Design, synthesis, and characterization of potent, slow-binding inhibitors that are selective for gelatinases. J Biol Chem 2002;277:11201-7. DOI PubMed

216. Johnson AR, Pavlovsky AG, Ortwine DF, et al. Discovery and characterization of a novel inhibitor of matrix metalloprotease-13 that reduces cartilage damage in vivo without joint fibroplasia side effects. J Biol Chem 2007;282:27781-91. DOI PubMed

217. Chetty C, Bhoopathi P, Joseph P, Chittivelu S, Rao JS, Lakka S. Adenovirus-mediated small interfering RNA against matrix metalloproteinase-2 suppresses tumor growth and lung metastasis in mice. Mol Cancer Ther 2006;5:2289-99. DOI PubMed

218. Dorecka M, Francuz T, Garczorz W, Siemianowicz K, Romaniuk W. The influence of elastin degradation products, glucose and atorvastatin on metalloproteinase-1, -2, -9 and tissue inhibitor of metalloproteinases-1, -2, -3 expression in human retinal pigment epithelial cells. Acta Biochim Pol 2014;61:265-70. PubMed

219. Luan Z, Chase AJ, Newby AC. Statins inhibit secretion of metalloproteinases-1, -2, -3, and -9 from vascular smooth muscle cells and macrophages. Arterioscler Thromb Vasc Biol 2003;23:769-75. DOI PubMed

220. Ichihara S, Noda A, Nagata K, et al. Pravastatin increases survival and suppresses an increase in myocardial matrix metalloproteinase activity in a rat model of heart failure. Cardiovasc Res 2006;69:726-35. DOI PubMed

221. Chen Q, Jin M, Yang F, Zhu J, Xiao Q, Zhang L. Matrix metalloproteinases: inflammatory regulators of cell behaviors in vascular formation and remodeling. Mediators Inflamm 2013;2013:928315. DOI PubMed PMC

222. Serra R, Gallelli L, Buffone G, et al. Doxycycline speeds up healing of chronic venous ulcers. Int Wound J 2015;12:179-84. DOI PubMed

223. Renkiewicz R, Qiu L, Lesch C, et al. Broad-spectrum matrix metalloproteinase inhibitor marimastat-induced musculoskeletal side effects in rats. Arthritis Rheum 2003;48:1742-9. DOI PubMed

224. Chiarelli N, Carini G, Zoppi N, Ritelli M, Colombi M. Transcriptome analysis of skin fibroblasts with dominant negative COL3A1 mutations provides molecular insights into the etiopathology of vascular Ehlers-Danlos syndrome. PLoS One 2018;13:e191220. DOI PubMed PMC

225. Greenberg BR, Golde DW. Erythropoiesis in familial erythrocytosis. N Engl J Med 1977;296:1080-4. DOI PubMed

226. Ang SO, Chen H, Hirota K, et al. Disruption of oxygen homeostasis underlies congenital Chuvash polycythemia. Nat Genet 2002;32:614-21. DOI PubMed

227. Gordeuk VR, Sergueeva AI, Miasnikova GY, et al. Congenital disorder of oxygen sensing: association of the homozygous Chuvash polycythemia VHL mutation with thrombosis and vascular abnormalities but not tumors. Blood 2004;103:3924-32. DOI PubMed

228. Banka S, Chervinsky E, Newman WG, et al. Further delineation of the phenotype of severe congenital neutropenia type 4 due to mutations in G6PC3. Eur J Hum Genet 2011;19:18-22. DOI PubMed PMC

229. Yin H, Zhang X, Wang J, et al. Downregulation of desmuslin in primary vein incompetence. J Vasc Surg 2006;43:372-8. DOI PubMed

230. Urbanek T, Skop B, Wiaderkiewicz R, et al. Smooth muscle cell apoptosis in primary varicose veins. Eur J Vasc Endovasc Surg 2004;28:600-11. DOI PubMed

231. Le Flem L, Mennen L, Aubry ML, et al. Thrombomodulin promoter mutations, venous thrombosis, and varicose veins. Arterioscler Thromb Vasc Biol 2001;21:445-51. DOI PubMed

232. Wang Q, Timur AA, Szafranski $\mathrm{P}$, et al. Identification and molecular characterization of de novo translocation $\mathrm{t}(8 ; 14)(\mathrm{q} 22.3 ; \mathrm{q} 13)$ associated with a vascular and tissue overgrowth syndrome. Cytogenet Cell Genet 2001;95:183-8. DOI PubMed PMC

233. Tian XL, Kadaba R, You SA, et al. Identification of an angiogenic factor that when mutated causes susceptibility to KlippelTrenaunay syndrome. Nature 2004;427:640-5. DOI PubMed PMC

234. Fang J, Dagenais SL, Erickson RP, et al. Mutations in FOXC2 (MFH-1), a forkhead family transcription factor, are responsible for the hereditary lymphedema-distichiasis syndrome. Am J Hum Genet 2000;67:1382-8. DOI PubMed PMC

235. Brice G, Mansour S, Bell R, et al. Analysis of the phenotypic abnormalities in lymphoedema-distichiasis syndrome in 74 patients with FOXC2 mutations or linkage to 16q24. J Med Genet 2002;39:478-83. DOI PubMed PMC

236. Mellor RH, Brice G, Stanton AW, et al. Mutations in FOXC2 are strongly associated with primary valve failure in veins of the lower limb. Circulation 2007;115:1912-20. DOI PubMed

237. Scappaticci S, Capra E, Cortinovis M, et al. Cytogenetic studies in venous tissue from patients with varicose veins. Cancer Genet Cytogenet 1994;75:26-30. DOI PubMed

238. Sam RC, Burns PJ, Hobbs SD, et al. The prevalence of hyperhomocysteinemia, methylene tetrahydrofolate reductase C677T mutation, and vitamin B12 and folate deficiency in patients with chronic venous insufficiency. J Vasc Surg 2003;38:904-8. DOI PubMed

239. Sverdlova AM, Bubnova NA, Baranovskaya SS, Vasina VI, Avitisjan AO, Schwartz EI. Prevalence of the methylenetetrahydrofolate reductase (MTHFR) C677T mutation in patients with varicose veins of lower limbs. Mol Genet Metab 1998;63:35-6. DOI PubMed

240. Gemmati D, Federici F, Catozzi L, et al. DNA-array of gene variants in venous leg ulcers: detection of prognostic indicators. $J$ Vasc 
Surg 2009;50:1444-51. DOI PubMed

241. Nagy N, Szolnoky G, Szabad G, et al. Single nucleotide polymorphisms of the fibroblast growth factor receptor 2 gene in patients with chronic venous insufficiency with leg ulcer. J Invest Dermatol 2005;124:1085-8. DOI PubMed

242. Janssens D, Michiels C, Guillaume G, Cuisinier B, Louagie Y, Remacle J. Increase in circulating endothelial cells in patients with primary chronic venous insufficiency: protective effect of Ginkor Fort in a randomized double-blind, placebo-controlled clinical trial. J Cardiovasc Pharmacol 1999;33:7-11. DOI PubMed

243. Geroulakos G, Nicolaides AN. Controlled studies of Daflon $500 \mathrm{mg}$ in chronic venous insufficiency. Angiology 1994;45:549-53. PubMed

244. Falanga V, Fujitani RM, Diaz C, et al. Systemic treatment of venous leg ulcers with high doses of pentoxifylline: efficacy in a randomized, placebo-controlled trial. Wound Repair Regen 1999;7:208-13. DOI PubMed

245. Kalus U, Koscielny J, Grigorov A, Schaefer E, Peil H, Kiesewetter H. Improvement of cutaneous microcirculation and oxygen supply in patients with chronic venous insufficiency by orally administered extract of red vine leaves AS 195: a randomised, double-blind, placebo-controlled, crossover study. Drugs R D 2004;5:63-71. DOI PubMed

246. Milio G, Mina C, Cospite V, Almasio PL, Novo S. Efficacy of the treatment with prostaglandin E-1 in venous ulcers of the lower limbs. J Vasc Surg 2005;42:304-8. DOI PubMed

247. Kahle B, Leng K. Efficacy of sclerotherapy in varicose veins-- prospective, blinded, placebo-controlled study. Dermatol Surg 2004;30:723-8; discussion 728. DOI PubMed 